\title{
Stan górnictwa i hutnictwa w kluczu samsonowskim w świetle lustracji z I 809 roku
}

\section{The State of Mining and Metallurgy in the Samsonów Complex in the Light of the Survey from 1809}

The article presents the Survey of the Samsonów complex from 1809, with a historical commentary. The document contains information on the condition of the mining and metallurgy industry, with particular emphasis on blast furnaces in Samsonów and Szałas, fryers, ore supply, organisation of miners' work, supply of wood for charring, and organisation of charcoal production.

Keywords: mining, metallurgy, Old-Polish Industrial Region, Samsonów, Duchy of Warsaw Słowa kluczowe: górnictwo, hutnictwo, Staropolski Okręg Przemysłowy, Samsonów, Księstwo Warszawskie

W zbiorach Archiwum Państwowego w Radomiu, w zespole zatytułowanym Zarząd Rolnictwa i Dóbr Państwowych Guberni Radomskiej, Kieleckiej, Lubelskiej, Siedleckiej znajduje się jednostka zawierająca dokumenty z lustracji przeprowadzonej na terenie rządowej ekonomii samsonowskiej w 1809 r. ${ }^{1}$ Poszyt liczy łącznie 307 zapisanych stron. W jego skład wchodzą dwa nieznacznie różniące się egzemplarze dokumentu w formie minuty (s. 1-31) oraz czystopisu (s. 70-96), stanowiącego raport (sprawozdanie) z dokonanej kontroli. Rękopisy zostały sporządzone przez dwie różne osoby, a następnie podpisane przez lustratora. Opisywana jednostka zawiera także inne, bardziej szczegółowe dokumenty dotyczące spraw klucza samsonowskiego, z których część stanowi załączniki do wymienionego raportu (s. 106-108, 132-266, 271-279). Rękopisy sporządzono w języku polskim, z pojedynczymi wtrąceniami łacińskimi. Sprawozdanie to nie było dotychczas szerzej wykorzystywane przez badaczy².

1 Archiwum Państwowe w Radomiu [APR], zesp. 44 Zarząd Rolnictwa i Dóbr Państwowych Guberni Radomskiej, Kieleckiej, Lubelskiej, Siedleckiej, sygn. 213 Lustracja ekonomii samsonowskiej, 1809 r.

$2 \mathrm{Na}$ informacje dotyczące konstrukcji wielkich pieców w Samsonowie i Szałasie, zabudowań samsonowskiego zakładu wielkopiecowego oraz zasadności postulatów w zakresie przebudowy pieców i utworzenia zbiorników 
W wyniku wojny polsko-austriackiej w 1809 r. w skład Księstwa Warszawskiego włączony został obszar Nowej Galicji, obejmujący teren Staropolskiego Okręgu Przemysłowego. Władze Księstwa podjęły wkrótce działania mające na celu zwiększenie produkcji przejętych zakładów górniczo-hutniczych na potrzeby wojskowe³. Przedsięwzięcie to zostało poprzedzone rozpoznaniem ich aktualnego stanu pod względem wyposażenia technicznego, organizacji prac, zaopatrzenia w rudę i paliwo oraz możliwości produkcyjnych. Sformułowano przy tym postulaty w zakresie poprawy istniejącej sytuacji. W kręgu zainteresowania nowych władz znalazł się między innymi obszar przemysłowego klucza samsonowskiego, wchodzącego pierwotnie w skład dóbr biskupów krakowskich, które zostały upaństwowione na mocy postanowień Sejmu Czteroletniego. W 1789 r. w granicach tego klucza znajdowało się 18 wsi $^{4}, 8$ wójtostw ${ }^{5}$ i 2 folwarki ${ }^{6}$, pracowały dwa wielkie piece: w Samsonowie (wystawiony w 1778 r.) i w Szałasie Nowym (zbudowany w 1773 r. $^{7}$ ), surówkę przerabiano w 9 fryszerkach ${ }^{8}$. Do przeprowadzenia lustracji zakładów samsonowskich wydelegowany został Michał Odrowąż-Strasz ${ }^{9}$, aktywny uczestnik życia

rezerwowych na Bobrzy powoływał się Eugeniusz Krygier, cytując przy tym niewielkie fragmenty rękopisu; E. Krygier, Z historii budownictwa zakładów wielkopiecowych w Zagłębiu Staropolskim. Samsonów 17781822, „Kwartalnik Historii Kultury Materialnej” 1965, nr 1, s. 12-13, 18, 35. Należy tu zauważyć, iż autor ten błędnie zinterpretował informację dotyczącą poruszanych przez koło wodne płuczek do rudy, przypisując je zakładowi wielkopiecowemu w Samsonowie; cytowany przez niego passus odnosił się mianowicie do urządzeń istniejących w innych zakładach („W naszych fabrykach”), o czym świadczy także dalszy fragment tekstu: „A że tu takowej machiny nie masz, więc korzystniej by było przy piecu wielkim w skrzynie złożoną rudę, naprawiwszy rynienkę od pogródek piecowych, przez ludzi gracami płukać kazać"; ibid., s. 18; APR, zesp. 44, sygn. 213, s. 76-77.

3 I. Ihnatowicz, Gospodarka polska od rozbiorów do upadku Księstwa warszawskiego. Kształtowanie się układu kapitalistycznego, [w:] B. Zientara, A. Mączak, I. Ihnatowicz, Z. Landau, Dzieje gospodarcze Polski do roku 1939, Warszawa 1988, s. 334.

4 Bobrza, Ćmińsk, Długojów, Janaszów, Kaniów, Kołomań, Kopcie, Kucębów, Odrowążek, Samsonów, Sorbin, Suchyniów, Szałas Nowy, Szałas Stary, Światełek, Tumlin, Umer, Zagnańsk.

5 Adamów, Bartków, Ciosowa, Ćmińsk, Jasiów, Tumlin, Wykień, Zbrojów.

6 Samsonów i Kajetanów.

7 Józef Osiński (a za nim część innych autorów) jako datę budowy wielkiego pieca w Szałasie podaje 1774 r.; J. Osiński, Opisanie polskich żelaza fabryk..., Warszawa 1782, s. 51.

8 Archiwum Państwowe w Kielcach [APK], zesp. 1 Rząd Gubernialny Radomski, sygn. 10200, Lustracja klucza samsonowskiego, 1789 r., s. 18-167; zob. także m.in. H. Łabęcki, Górnictwo w Polsce. Opis kopalnictwa i hutnictwa polskiego pod względem technicznym, historyczno-statystycznym i prawnym, t. 1, Warszawa 1841, s. 328-329, 333; J. Pazdur, Materiały do dziejów hutnictwa żelaza w Polsce w XVIII wieku, „Studia z Dziejów Górnictwa i Hutnictwa" t. 1, 1957, s. 323-327; E. Krygier, op. cit., s. 11; Z. Guldon, J. Kaczor, Górnictwo i hutnictwo w Staropolskim Okręgu Przemysłowym w drugiej połowie XVIII wieku, Kielce 1994, s. 41-44.

9 Michał Viktor Odrowąż-Strasz z Białaczowa (1744-1824); miecznik opoczyński (1767 r.), uczestnik konfederacji barskiej, w latach 1773-1775 z ramienia sejmu wchodził w skład komisji rozsądzających spory o dobra, następnie łowczy opoczyński (1776 r.), podczas sejmiku w Opatowie (1781 r.) został wybrany deputatem na Trybunał Koronny, w tym samym roku objął funkcję podsędka radomskiego. Poseł sandomierski na Sejm Wielki (1788 r.), gdzie związał się ze stronnictwem patriotycznym; zabierał glos głównie w sprawach skarbowych, w $1790 \mathrm{r}$. wybrano go do składu deputacji koekwacyjnej, mającej zrównać wysokość podatków płaconych przez poszczególne jednostki terytorialne państwa. Pełnił także obowiązki sędziego sejmowego. Należał do Zgromadzenia Przyjaciół Konstytucji Rządowej „Fiat lux". W 1791 r. wszedł w skład deputacji, która miała ustalić sposoby pokrycia deficytu skarbowego oraz podjąć decyzję w sprawie dalszych losów królewszczyzn. Podczas sejmiku w Opatowie (1792 r.) został obrany komisarzem granicznym. W 1794 r. wchodził w skład Komisji Porządkowej dla powiatów radomskiego i opoczyńskiego; w wyniku insurekcji kościuszkowskiej oraz działań władz zaborczych poniósł znaczne straty materialne. W okresie Księstwa Warszawskiego wrócił do aktywności publicznej, w latach 1807-1811 prawdopodobnie zasiadał w sądzie policji prostej. Od 1810 r. pełnił funkcję prezesa Trybunału Cywilnego Pierwszej Instancji w Radomiu. W 1818 r. został senatorem kasztelanem, wchodząc w skład komisji Praw Cywilnych i Kryminalnych, jednak wkrótce, ze względu na podeszły wiek i stan zdrowia, wycofał się z życia publicznego. Był średniozamożnym właścicielem ziemskim, posiadając majątek Trojanowice koło Żarnowa; Z. Anusik, Strasz (Odrowąż Strasz) Michał z Białaczowa h. Odrowąż (ok. 1740-1824), [w:] Polski Słownik Biograficzny, t. 44/2, z. 181, red. A. Romanowski, Warszawa - Kraków 2006, s. 210-213; geneteka.genealodzy. 
politycznego doby Sejmu Czteroletniego, cieszący się szacunkiem szlachty sandomierskiej, posiadający doświadczenie z zakresu skarbowości, a przy tym były dzierżawca zakładów górniczo-hutniczych ${ }^{10}$. Opracowany przez niego dokument składa się z części wstępnej, zawierającej ogólne dane dotyczące wizytowanej jednostki gospodarczej, przedstawienie osoby zarządcy wraz z jego pełnomocnictwami i ogólnego profilu produkcji, a także części zasadniczej, podzielonej na 6 punktów tematycznych, odnoszących się kolejno do spraw wielkich pieców, zaopatrzenia w rudę, organizacji pracy górników, zaopatrzenia w drewno do produkcji węgla drzewnego, organizacji pracy węglarzy oraz funkcjonowania fryszerek. Główną część manuskryptu zapisano w układzie pagina fracta, gdzie po stronie lewej opisano stan istniejący, po prawej zaś - postulaty w zakresie jego poprawy.

Publikując tekst lustracji oparto się na zasadach sformułowanych w instrukcji wydawniczej Kazimierza Lepszego ${ }^{11}$, w odniesieniu zaś do ustępów łacińskich - na Instrukcji wydawniczej dla średniowiecznych źródeł historycznych ${ }^{12}$, jednakże ze względu na specyfikę źródła dokonano kilku modyfikacji. Za podstawę wydania przyjęto czystopis, odmianki tekstu zamieszczając w przypisach dolnych. Zrezygnowano z oddzielnych przypisów tekstowych i rzeczowych. Niektóre wyrazy o podwójnym złożeniu liter: „allegacyja”, „approbowany”, „artylleryja”, „defficit”, „Gallicyja”, „kassa”, „officjalista”, „rapport”, „summa”, zmodyfikowano, zapisując jako: „alegacyja”, „aprobowany”, „artyleryja”, „deficyt”, „Galicyja”, „kasa”, „oficjalista”, „raport”, „suma”. Zgodnie z instrukcją wydawniczą występujące w tekście wyrazy „szrzedniey”, „szrzednio”, „szrzodku” zapisano w formie: „śrzedniej”, „śrzednio”, „śrzodku”. Uwspółcześniono pisownię niektórych wyrazów, zamieniając „austryjacki" na „austriacki”, „bierąc” na „biorąc”, „bydź” na „być”, ,jasionowych” na „jesionowych”, „przed tym” na „przedtem”, „przekładałem” na „przedkładałem”, „przywięzuje” na „przywiązuje”, „roszcie” na „ruszcie”, „sałasy” na „szałasy”, „sałaski” na „szałaski”, „świce” na „świece”, „wąższego” na „węższego”. Wyrazy „nadgradzać”, „nadgroda” i „wynadgrodzić” zapisano odpowiednio jako: „nagradzać”, „nagroda” i „wynagrodzić”. Zmodernizowano pisownię niektórych słów zakończonych literami "ą" i „ę"; "galeryją" na "galeryję”, „inspekcyją" na „inspekcyję”, „konsygnacyją” na „konsygnacyję”, „kopalnią” na „kopalnię”, „lokacyją” na „lokacyję”, „moję” na „moją”, „opinią” na „opinię”, „rafinacyją" na „rafinacyję”, „substancyją" na „substancyję”, „swoję” na „swoją”, „wszystkę” na „wszystką". Oryginalną formę pozostawiono w przypadku wyrazów: „czasiech” (czasach), „deszczek” (desek), „jodłowemi” (jodłowymi), „któren” (który), „lanców” (lanc), "najgorszemi” (najgorszymi), „niemi” (nimi), „onę” (ją), „porządkowemi” (porządkowymi), „przedaż” (sprzedaż), „przydrobniejsza” (bardziej drobna), „robiemy” (robimy), „rolniczem” (rolniczym), „samem” (samym), „szlufowaniu” (szlifowaniu), „frysierz” (fryszerz), „lemierz" i „milerz” (mielerz), „siąg” (sąg), „świerkowemi” (świerkowymi), „wciągnieni” (wciągnięci), "wojskowemi” (wojskowymi), „zostającemi” (zostającymi). Zachowano występujące w tekście oboczności form: „czasiech” - „czasach”, „który” - „któren”, „le-

$\mathrm{pl} /$ index.php?op $=\mathrm{gt} \&$ lang $=$ pol\&bdm $=\mathrm{B} \& \mathrm{w}=07 \mathrm{mz} \& \mathrm{rid}=\mathrm{B} \&$ search_lastname $=$ Strasz\&search_name $=$ Micha†\&search_lastname $=$ \&search_name2 $=$ \&from_date $=1744 \&$ to_date $=1744 \&$ exac $=1$ [dostęp $2 \overline{8} .02 .2021$ ] .

10 APR, zesp. 44, sygn. 213, s. 7, 74. Autorowi nie udało się ustalić lokalizacji tych zakładów; w lustracji folwarków wchodzących w skład klucza samsonowskiego M. Odrowąż-Strasz odnotował: „Znam fabryki, bo je dzierżawnie trzymałem, miałem w miejscu folwark"; ibid., s. 34.

11 Instrukcja wydawnicza dla źródeł historycznych od XVI do połowy XIX wieku, red. K. Lepszy, Wrocław 1953.

12 Instrukcja wydawnicza dla średniowiecznych źródeł historycznych, Kraków 1925. 
mierz" - „milerz”, „niemi” - „nimi”, „tem” - „tym”. Łacińskie fragmenty tekstu zapisano kursywą, w przypisach dolnych zamieszczając ich tłumaczenie. Wyrazy polskie pochodzenia łacińskiego zapisano antykwą. Uwspółcześniono pisownię wielkich liter, zachowując je w przypadku zwrotów tytularnych np. „Imć”, „Pana” oraz odnoszących się do instytucji państwowych, np. „Skarb” (w znaczeniu skarb państwa). Zmodernizowano pisownię nazw miejscowych, formy: Okulec, Sałas, Serwinów, Rozsochy/Rossochy zastępując odpowiednio przez: Okolec, Szałas, Serbinów, Rosochy. Nazwę Położnia zastąpiono właściwą formą Połaźnia, występującą w minucie. W przypadku toponimu Kietlanka/Kitlonka, którego właściwą formę trudno jednoznacznie ustalić, przyjęto wariant zgodnie z czystopisem. Liczebniki z przedziału od 1 do 10 zapisano zgodnie z formą występującą w oryginale, tj. słownie lub przy użyciu cyfr arabskich, natomiast liczebniki o wartości wyższej zapisano cyframi arabskimi. Zapisy cyfrowo-literowe zastąpiono formą literową, np. „3cią”, „7mym”, „9tym”, „10go” zapisano odpowiednio: „trzecią”, „siódmym”, „dziewiątym”, „dziesiątego". Uzupełnienia tekstu zamieszczane w nawiasach kwadratowych ograniczono do przypadków uzasadnionych poprawą jego czytelności. Wszystkie występujące w źródle skróty rozwinięto według powszechnie przyjętego brzmienia: JWo - J[aśnie]W[ielmożneg]o, W - W[ielmożny], JO - J[aśnie] O[świeconego], Imci - J[egomości], r[oku] b[ieżącego], pozostawiając skrótowiec „Imć”. Kolejne karty rękopisu zapisano kursywą w nawiasach kwadratowych, zgodnie z paginacją archiwalną. Dla zapewnienia lepszej czytelności tekstu zmodyfikowano interpunkcję i podział na akapity, a nadmiernie rozbudowane rozdzielono średnikami.

Edytowane źródło zawiera wiele wartościowych informacji zarówno z zakresu historii gospodarczej, jak i dziejów techniki górniczo-hutniczej Staropolskiego Okręgu Przemysłowego. W punkcie lustracji dotyczącym wielkich pieców autor krótko scharakteryzował piec samsonowski oraz nieco mniejszy w Szałasie Nowym, podając przy tym interesujące szczegóły na temat sposobu znakowania odlewów surówki (tzw. gęsi) przeznaczonych do świeżenia we fryszerkach. Zwrócił przy tym uwagę na przestoje produkcyjne wynikające ze złego zaopatrzenia w paliwo i rudę, która ponadto była złej jakości, a w przypadku Samsonowa - także z powodu częściowego zniszczenia urządzeń zakładu (po rocznej przerwie tutejszy piec ponownie uruchomiono 9 sierpnia 1809 r.). Odpowiedzialnością za problemy zaopatrzeniowe autor obarczył pracowników administracji, zaniedbujących swoje obowiązki w zakresie nadzoru nad pracą górników oraz niewłaściwie organizujących pracę węglarzy ${ }^{13}$. W celu podniesienia wydajności wielkiego pieca w Samsonowie lustrator postulował zwiększenie jego objętości poprzez podwyższenie szybu oraz zastosowanie nowej, cieńszej futrówki, jednakże wobec ogólnie złego stanu obiektu było to rozwiązanie tymczasowe, wymuszone względami finansowymi i koniecznością jak najszybszego wznowienia produkcji; w dokumencie wyraźnie wskazano na potrzebę zastąpienia istniejącego obiektu nowym. Mając na uwadze zapewnienie ciągłości pracy zakładów, zwrócono uwagę na potrzebę utrzymywania stałych rezerw rudy i węgla ${ }^{14}$.

Opisując kwestie zaopatrzenia w rudę, autor zwrócił uwagę na jej złą jakość, wynikającą z niewłaściwego czyszczenia oraz składowania pod gołym niebem, tak przy kopalniach, jak i na terenie zakładów wielkopiecowych; niedostatecznie wyprażona, jeszcze 
wilgotna ruda trafiała do pieca, gdzie gwałtownie rozprężająca się para wodna powodowała przemieszanie wsadu, zakłócając proces wytopu. Odnosząc się do funkcjonowania kopalń lustrator przytoczył interesującą uwagę dotyczącą wymagań nadzorców polskich i niemieckich względem średnicy szybów; o ile Niemcy nakazywali by wynosiła ona jeden sążeń austriacki (około $2 \mathrm{~m}$ ), o tyle Polacy pozostawiali w tym zakresie wolną rękę górnikom, którzy chcąc udostępnić złoże możliwie najmniejszym wysiłkiem z reguły kopali węższe szyby. W opisie znalazły się także informacje dotyczące stosowanych wówczas w innych ośrodkach sposobów zabezpieczania szybów przed deszczem, metod ręcznego i mechanicznego oczyszczania rudy, zasad jej odbioru, segregacji i przechowywania. W odniesieniu do miejscowych zakładów, nie posiadających wówczas poruszanych siłą kół wodnych płuczek mechanicznych, postulowano jedynie ręczne oczyszczanie rudy (na co wpływ miały zapewne kwestie finansowe i ograniczenia czasowe) oraz wzniesienie w Samsonowie i Szałasie szop do jej przechowywania. Zwrócono uwagę, że składowanie odebranego urobku w pobliżu kopalń stwarza ryzyko jego kradzieży w celu ponownego zdania. W kontekście wnioskowanej potrzeby zabezpieczania szybów jatami oraz składowania rudy pod zadaszeniem ciekawa jest odnotowana przez lustratora relacja górników, według której budowle takie stosowano w okresie przedrozbiorowym, rezygnując z nich dopiero pod zarządem austriackim. Ciekawe są także spostrzeżenia autora dotyczące zalet przewożenia rudy z wykorzystaniem sań w okresie zimowym w porównaniu z transportem kołowym. Zakłady zaopatrywane były wówczas przez 12 kopalń ${ }^{15}$, bezpośrednio obsługiwanych przez 57 osób.

W świetle ustaleń lustratora miejscowi górnicy pracowali wcześniej w kopalni miedzianogórskiej, gdzie trudnili się wyłącznie pracami wydobywczymi. Po wyodrębnieniu Miedzianej Góry spod zarządu w Samsonowie częściowo musieli się oni zająć uprawą roli, co niekorzystnie odbiło się na zaopatrzeniu miejscowych zakładów w rudę; wobec niskiego wynagrodzenia (które zaliczano im na poczet pańszczyzny) chłopi-górnicy skłonni byli raczej poświecić się własnym gospodarstwom niż dokładać starań dla zapewnienia terminowości dostaw urobku o odpowiedniej jakości, na co nakładały się także zaniedbania nadzoru. Przerywanie prac skutkowało przy tym zalewaniem wyrobisk, które nie zawsze udawało się następnie odwodnić. Interesująca przy tym jest wzmianka na temat stosowanego w wyrobiskach oświetlenia przy użyciu świec łojowych. W ramach poprawy istniejącej sytuacji, stosownie do rozwiązań praktykowanych w innych zakładach, autor raportu zaproponował zwiększenie stawki wynagrodzenia za głębienie szybu przed osiągnięciem złoża, zaopatrywanie górników w świece, oraz przeznaczenie byłego folwarku jasiowskiego na osadę górniczą, co miało wiązać się adaptacją istniejących 4 budynków mieszkalnych oraz budową kolejnych 12, a także przydzieleniem na potrzeby mieszkańców niewielkich działek ziemi, przy obowiązku uiszczania stosunkowo niedużego czynszu. Pozostali chłopi-górnicy mieli zostać przekierowani do pracy przy obsłudze zakładów ${ }^{16}$.

W odniesieniu do zaopatrzenia $\mathrm{w}$ drewno na potrzeby produkcji węglarskiej lustracja wykazała zbyt małe zapasy w stosunku do bieżących potrzeb wielkich pieców i fryszerek, za co obarczono odpowiedzialnością zarządców austriackich. Wśród nieprawidłowości 
stwierdzono wyrabianie sągów w miejscach niedostępnych, niewłaściwy termin pozyskania, uniemożliwiający dostateczne przesuszenie surowca. Kolejnym zarzutem względem administracji austriackiej było niewykorzystanie na potrzeby hutnictwa ogromnych ilości drewna pozostałych po huraganie z 1800 r. i niepotrzebne w tych warunkach uszczuplenie zasobów leśnych poprzez wycinkę drzew stojących ${ }^{17}$.

Uchybienia organizacyjne stwierdzono także oceniając pracę węglarzy (wówczas zaledwie dziesięciu), m.in. brak wcześniejszego ustalania potrzebnej ilości produktu, co niejednokrotnie skutkowało koniecznością przedwczesnego rozbierania mielerzy i powstającymi przy tym stratami. Z punktu widzenia techniki zwęglania drewna interesująca jest wzmianka na temat stosowania w mielerzach niewłaściwych opon z gałęzi zamiast ziemnych, które dopuszczając do wnętrza zbyt dużo powietrza powodowały częściowe spopielenie drewna ${ }^{18}$.

W stosunku do 1789 r. lustracja wykazała spadek liczby fryszerek z 9 do 5, przy czym zakłady w Kaniowie, Janaszowie, Jasiowie i jeden z obiektów w Suchyniowie zostały zniszczone przez powódź z 9 sierpnia 1806 r. ${ }^{19}$, druga zaś z fryszerek suchyniowskich spłonęła. Z tej liczby odbudowę podjęto jedynie w Kaniowie. W jednej z fryszerek podjęto przy tym produkcję stali. W dokumencie zawarto uwagi na temat stanu urządzeń hydrotechnicznych i zaopatrzenia wodnego zakładów. Czynne wówczas fryszerki nie były w stanie sprostać potrzebom dwóch wielkich pieców w perspektywie ich planowego uruchomienia z wykorzystaniem pełnej mocy produkcyjnej. Uwzględniając aktualne warunki hydrologiczne autor wystąpił z postulatem odbudowy dwóch fryszerek w Suchyniowie oraz wzniesienia dwóch nowych obiektów w Bobrzy, przy jednoczesnej likwidacji tamtejszego młyna. Ze względu na zbyt niskie zasoby wodne zniszczone spiętrzenia po fryszerce jasiowskiej i janaszowskiej proponował przy tym przekształcić w zbiorniki rezerwowe, zasilające niżej położone zakłady ${ }^{20}$. Zwrócił ponadto uwagę na potrzebę wykorzystania w procesie wielkopiecowym żużli pozostałych po produkcji stali ${ }^{21}$.

Na końcu rękopisu autor odwołał się do załączników, które znajdują się w dalszej części poszytu. W dokumencie zatytułowanym „Sumariusz z inwentarzy pańszczyzny ułożony, w którym optecty gruntowe pańszczyznej i inne całoroczne przez poddanych ponoszone ciężary umieszczone są" (s. 106-108) w formie tabelarycznej dla poszczególnych wsi wchodzących w skład klucza wyszczególniono liczbę gospodarstw, wysokość świadczeń pieniężnych (wysokość czynszu emfiteutycznego ${ }^{22}$ z użytkowanych gruntów,

18 Ibid., s. 91-93.

19 T. Mencel, Galicja Zachodnia 1795-1809. Studium z dziejów ziem polskich zaboru austriackiego po III rozbiorze, Lublin 1976, s. 238.

20 W tym kontekście nie można zgodzić się z opinią Eugeniusza Krygiera, według którego przeznaczenie tych zbiorników na cele rezerwowe pozbawiłoby zakład wielkopiecowy w Samsonowie dwóch fryszerek; E. Krygier, op. cit., s. 35 . W 1809 r. fryszerki te bowiem już nie istniały, nadto autor lustracji postulował zbudowanie dwóch nowych fryszerek w lokalizacji lepszej pod względem zaopatrzenia w wodę (Bobrza).

21 APR, zesp. 44, sygn. 213, s. 93-96.

22 Emfiteuza - odmiana długoterminowej dzierżawy; nadanie określonych dóbr na wieczność lub na ustalony, długi okres (z reguły kilkudziesięcioletni), z prawem do jego przekazania spadkobiercom lub osobom trzecim, w zamian za stały, niezależny od uzyskiwanych dochodów roczny czynsz (tzw. kanon). Emfiteuza upowszechniła się w XVIII w. Według ustawy z 1775 r. była to jedyna dopuszczalna forma dzierżawy królewszczyzn, zaś Konstytucja 3 maja $1791 \mathrm{r}$. oraz uniwersał połaniecki (1794 r.) zalecały stosowanie emfiteuzy względem dóbr użytkowanych przez chłopów; S. Russocki, Emfiteuza, [w:] Encyklopedia historii gospodarczej Polski do 1945 roku $(A-N)$, red. A. Maczak, Warszawa 1981, s. 160-161. 
placowego i siekiernego ${ }^{23}$ ), wysokość świadczeń w naturze (wielkość zsypu owsa, liczba kur i jaj), wysokość robocizny ciągłej (pańszczyzna, szarwark ${ }^{24}$, suche dni²5) i pieszej (pańszczyzna, szarwark, suche dni, powaby ${ }^{26}$, kądziel $^{27}$, kośne, grabne, darmiszę ${ }^{28}$ ). Obciążenie poszczególnych wsi było zróżnicowane, tak w wymiarze ilościowym, jak i w liczbie nałożonych świadczeń. Łączna pańszczyzna w skali całego klucza wynosiła 15848 dniówek ciągłych i 14594 dniówki piesze. Dokument sporządzono 18 września 1809 r. w Samsonowie, został on podpisany przez rachmistrza kuźnic Jana Aschnera oraz intendenta Jana Stoyanowskiego. Inwentarz budowli podzielono na dwa odrębne dokumenty, zawierające zestawione w formie tabelarycznej opisy poszczególnych obiektów z określeniem ich stanu. Obydwa sporządzono w Samsonowie 15 listopada 1809 r. Pierwszy z nich, zatytułowany „Inwentarz budynków kuźniczych, które podług poczynionej na gruncie lustracyi opisane zostały” (s. 132-188) sygnowany został przez Aschnera29. Drugi to „Inwentarz budowli ekonomicznych w jakim stanie dnia 14 lipca 1809 roku znajdowały się te dobra" (s. 189-266), podpisany przez Stoyanowskiego oraz pisarza urzędowego Walentego Hełczyńskiego ${ }^{30}$. Ostatni z załączników to „Konsygnacyja rekwizytów ruchomych do fabryk żelaznych należących" (s. 271-279), zawierająca wykaz sprzętów przypisanych do poszczególnych zakładów. Sporządzony 15 listopada 1809 r. w Samsonowie dokument sygnował Aschner ${ }^{31}$.

W świetle powyższej lustracji sytuacja przemysłu górniczo-hutniczego na terenie klucza samsonowskiego w okresie między 1789 a 1809 r. uległa generalnie pogorszeniu. Stan techniczny wielkiego pieca w Samsonowie był zły, niemal o połowę zmniejszyła się liczba fryszerek, regres zaznaczył się także w technice górniczej. Sytuacja ta w dużej

23 Siekierne - zryczałtowana opłata uiszczana przez poszczególne wsie za prawo do pozyskiwania drewna w lasach rządowych; zob. M. Siembab, A.J. Wójcik, Zarys dziejów huty żelaza w Ząbkowicach (1763-1794), Warszawa 2020, s. 99.

24 Szarwark - przymusowe świadczenia ludności chłopskiej związane z naprawą i budową dróg, grobel, mostów, czasem również obwarowań; w XIX-XX w. z reguły zamieniane (w całości lub częściowo) na opłaty pieniężne; J. Janczak, Szarwark, [w:] Encyklopedia historii gospodarczej Polski do 1945 roku (O-Ż), red. A. Maczak, Warszawa 1981, s. 353.

25 Suche dni - kwartalne świadczenie ludności chłopskiej, którego nazwa nawiązuje do powtarzającego się co trzy miesiące trzydniowego okresu (tzw. suche dni: środa, piątek i sobota) poświęconego szczególnym modłom liturgicznym w Kościele katolickim, podczas którego dawniej wiernych obowiązywał post; Słownik języka polskiego, t. 8, red. W. Doroszewski, Warszawa 1966, s.v. suchedni.

26 Powaby (tłoki, gwałty) - świadczenia ludności chłopskiej w postaci dodatkowej robocizny w ramach tzw. dni pomocnych (w okresach sezonowego nasilenia prac polowych); nie były one wliczane do zasadniczego wymiaru pańszczyzny. Powaby egzekwowano od XV w., na terenie Królestwa Polskiego w dobrach państwowych zniesiono je w 1817 r., zaś w prywatnych - w 1846 r.; M. Kamler, powaby, [w:] Encyklopedia historii gospodarczej Polski do 1945 roku (O-Ż), s. 117-118; idem, darmochy, [w:] Encyklopedia historii gospodarczej Polski do 1945 roku $(A-N)$, s. 135.

27 Świadczenie ludności chłopskiej związane z przędzeniem Inu; zob. APK, zesp. 1, sygn. 10200, s. 92.

28 Darmochy (daremszczyzny) - dodatkowe świadczenia ludności chłopskiej w formie robocizny nie wliczanej do zasadniczego wymiary pańszczyzny, egzekwowanej z reguły w okresach nasilenia prac polowych; dotyczyły $\mathrm{m}$. in. prac przy uprawie i obróbce Inu, strzyżeniu owiec i czyszczeniu wełny, pielęgnacji stawów, pracach przy sianie. Darmochy obowiązywały od XV w., w Królestwie Polskim zniesiono je razem z powabami; M. Kamler, darmochy, [w:] Encyklopedia historii gospodarczej Polski do 1945 roku (A-N), s. 135.

29 Dokument ten będzie tematem odrębnej publikacji.

30 Zakres powinności służbowych W. Hełczyńskiego określono następująco: „Nie tylko że rachunki zbożne, bydła i materiałów ekonomicznych prowadzi, lecz do załatwiania politycznych interesów etc. obowiązany"; APR, zesp. 44, sygn. 213, s. 102. Jak ustalił Marek Jerzy Minakowski (2017 r.), W. Hełczyński był jednym z antenatów Jana Nowaka Jeziorańskiego (1914-2005) ze strony matki; M.J. Minakowski, Hełczyńscy: szlachta, mieszczanie czy frankiści?, minakowski.pl/helczynscy-szlachta-mieszczanie-czy-frankisci/ [dostęp 28.02.2021].

31 APR, zesp. 44, sygn. 213, s. 98-108, 132-266, 271-279. 
mierze wynikała z zaniedbań i niewłaściwie sprawowanego zarządu, co niejednokrotnie zaznaczał autor lustracji, nota bene wyraźnie biorąc przy tym w obronę pracowników fizycznych i postulując rozwiązania mające przynieść poprawę ich ciężkiego położenia. Taka interpretacja byłaby jednak nadmiernym uproszczeniem. Nie uwzględnia ona bowiem działalności podjętej przez Antoniego von Schindlera, austriackiego dyrektora zakładów górniczych i hutniczych w Galicji Zachodniej, który w latach 1801-1806 w zakładzie samsonowskim wprowadził szereg usprawnień, m.in. zmodernizował wielki piec poprzez jego podwyższenie oraz wzmocnienie dmuchu, ulepszył młyn do kruszenia rudy oraz urządził mechaniczną tłucznie wapienia (topnika). W 1804 r. w Samsonowie powstała drutarnia. Ponad dwukrotnie wzrósł uzysk żelaza z rudy (z 12,75 do 27 funtów z cetnara), niemal dwukrotnie zaś wzrosła wydajność fryszerek. Von Schindler za zgodą władz centralnych podniósł przy tym płace urzędnikom oraz pracownikom fizycznym. Osiągnięcia te zniweczyła powódź z 1806 r.; spowodowanych przez nią zniszczeń nie udało się naprawić aż do 1808 r. ${ }^{32}$ Edytowane źródło jest świadectwem dobrego przygotowania merytorycznego lustratora do realizacji powierzonego mu zadania, wynikającego z praktycznej znajomości zagadnień górnictwa i hutnictwa oraz zasad ekonomii. Dokument ten, poparty innymi przykładami ${ }^{33}$, przemawia za twierdzeniem, że pod koniec XVIII w. i na początku XIX w. Polska dysponowała wykwalifikowaną, rodzimą kadrą techniczną, świadomie i trafnie angażowaną przez władze centralne w dziele rozwoju potencjału gospodarczego państwa.

\section{Tekst dokumentu}

[s. 69] Lustracyja fabryk żelaznych do dóbr narodowych prefektury samsonowskiej należących, na gruncie spisana ${ }^{34}$.

[s. 70] W imieniu Napoleona Wielkiego Cesarza Francuzów, Króla Włoskiego, Protektora Ligii Reńskiej [35]

Do Najwyższej Administracyi Dóbr Narodowych obydwóch Galicyi.

Od lustratora prefektury samsonowskiej w powiecie kieleckim leżącej.

Raport

Względem fabryki żelaznej i jej na teraz egzystencyi ${ }^{36}$ z opisem jej stanu w artykułach ogólnych jak jest, jak być powinien ${ }^{37}$, dowodami objaśniony.

Prefektura czyli klucz samsonowski, przedtem do biskupstwa krakowskiego należący,

32 T. Mencel, op. cit., s. 236-238; J. Szczepański, Modernizacja górnictwa i hutnictwa w Królestwie Polskim w I połowie XIX w. Rola specjalistów niemieckich i brytyjskich, Kielce 1997, s. 46.

33 Wymienić tu można lustratorów: Romualda Ostaszewskiego, Felicjana Przedwoszowskiego oraz Jana Kuszewskiego, którzy w 1789 r. na zlecenie Komisji Skarbu Koronnego dokonali wszechstronnej oceny stanu przemysłu górniczo-hutniczego na terenie klucza siewierskiego. Efektem ich pracy była dokumentacja dotycząca m. in. zasobów i klasyfikacji rud żelaza, techniki górniczej, zaopatrzenia w paliwo, lokalizacji zakładów produkcyjnych, technicznego wyposażenia fryszerek i wielkiego pieca w Ząbkowicach, organizacji i opłacalności produkcji, kosztów transportu żelaza, zapewnienia siły roboczej oraz kwestii wynagrodzeń dla kuźników. Co warte podkreślenia, w trosce o stan dostępnych zasobów leśnych lustratorzy ci postulowali wykorzystanie w procesach produkcyjnych miejscowych złóż węgla kamiennego, którego początki eksploatacji przypadają na ten okres; M. Siembab, A.J. Wójcik, op. cit., s. 17, 84-85, 99, 101-103, 117-118, 120.

34 W minucie w dolnej części karty dopisane inną ręką: Lustracyja dóbr Samsonowa.

35 W minucie dodane: etc., etc., etc.

36 W minucie: na teraz egzystującej.

37 W minucie: powinna. 
a przez Sejm Konstytucyjny na dobra narodowe zmieniony, nad którą co do fabryk żelaznych w tejże prefekturze egzystujących ma inspekcyję dozorczą i egzekwującą W[ielmoż] ny Babski ${ }^{38}$ kapitan Sztabu Generalnego mocą instrukcyi i rozkazu, do administracyi fabryk żelaznych w radomskim i kieleckim powiatach, już to od J[aśnie]W[ielmożne]go Wasilewskiego ${ }^{39}$ ordynatora, z rozkazu J[aśnie] O[świeconego] Książęcia J[egomoś]ci na dniu siódmym lipca r[oku] b[ieżącego] aprobowaną, dalej od J[aśnie]W[ielmożne]go Rembielińskiego ${ }^{40}$ intendenta obydwóch Galicyi, administracyję fabryk temuż Imć Panu Babskiemu nadającego, z zaleceniem aby najmniejszej części żelaza z tych fabryk nie przedawał; fundusze na utrzymanie tych z kas powiatowych pobierał, onych rachunek, i ogólnych percept $^{41}$ żelaza utrzymać i podawać starał się, a ostatecznie od [ ${ }^{42}$ ] Księcia J[egomoś]ci w Krakowie dnia pierwszego augusti ${ }^{33}$ r[oku] b[ieżącego] stosownie do pierwszych rozkazów administracyją opatrzony, zupełnie wszystkim rządzi, i rekwizytami wojskowemi, w laniu kul, w różnych gatunkach szlufowaniu onych, robieniu podków, grotów czyli lanców, tutaj w Samsonowie fabrykantów zatrudnia. Surowe żelazo jedno do Suchedniowa zabiera, z drugiego na fryszerkach tutejszych żelazo modelowe, które przez Suchedniów do Warszawy dla artyleryi przesyła, i stal surową na pałasze, które w Michałowie za Wąchockiem, rafinując wprzód w Suchedniowie, wyrabiają, kuć każe.

38 Franciszek Babski; od 1 VIII 1809 r. administrator fabryk żelaznych w powiecie kieleckim i radomskim, informator Juliana Ursyna Niemcewicza (1811 r.), który w swojej pracy przytoczył trzy obszerne opisy dóbr górniczych jego autorstwa („Opisanie fabryk samsonowskich w r. 1811”, „Opisanie Łubianki”, „Krótkie opisanie fabryk narodowych suchedniowskich"), inspektor górniczy (1818 r.), w 1824 r. jako radca hutniczy uczestniczył w naradach podczas objazdu górniczych zakładów rządowych przez ks. Franciszka Ksawerego Druckiego-Lubeckiego. Nadzorował funkcjonowanie fabryk samsonowskich, bzińsko-suchedniowskich, brodzko-starachowickich i radoszyckich. 17 IX 1826 r. został zawieszony w urzędowaniu pod zarzutem spowodowania spadku wydajności produkcji w podległych zakładach; APR, zesp. 44, sygn. 213, s. 3, 70; J.U. Niemcewicz, Podróże historyczne po ziemiach polskich między rokiem 1811 a 1828 odbyte, Paryż - Petersburg 1858, s. 15-19; N. GąsiorowskaGrabowska, Z dziejów przemysłu w Królestwie Polskim 1815-1918, Warszawa 1965, s. 199, 269, 479; J. Szczepański, op. cit., s. 134-135; M. Medyński, Od III rozbioru do końca pierwszej wojny światowej, [w:] P. Kardyś, K. Zemeła, M. Medyński, T. Wojewoda, S. Piątkowski, G. Miernik, M. Zawisza, Suchedniów monografia historyczna miasta i gminy, Suchedniów 2019, s. 148, 152. Szerzej na temat powstania dzieła Niemcewicza, losów rękopisu i okoliczności jego publikacji zob. Z.J. Wójcik, Świętokrzyskie w relacjach podróżniczych Juliana Ursyna Niemcewicza, [w:] Mijające krajobrazy Polski. Świętokrzyskie, red. A. Rembalski, Kielce 2014, s. 163-174.

39 Józef Wasilewski (1759-1831); uczestnik insurekcji kościuszkowskiej (kwatermistrz 2 regimentu, następnie kwatermistrz generalny), w Księstwie Warszawskim jako komisarz-ordonator był szefem administracji wojskowej w Ministerium Wojny (wydział 5), od 1812 r. generał brygady; Kalendarzik Polityczny, Chronologiczny i Historyczny na Rok Panski 1811 z Magistraturami Krajowemi, Warszawa 1811, s. 183-184; S. Herbst, Z dziejów wojskowych powstania kościuszkowskiego 1794 roku, Warszawa 1983, s. 56; M. Krzymkowski, P.M. Pilarczyk Protokoły Rady Ministrów Księstwa Warszawskiego, t. 1, (1808-1809), Poznań 2015, s. 113.

40 Rajmund Hiacynt Rembieliński (1774-1841); uczestnik insurekcji kościuszkowskiej, w 1807 r. komisarz likwidacyjny w Białymstoku, następnie (11 IX) prezes Deputacji Administracji części Białostockiego włączonej w granice Księstwa Warszawskiego, prefekt Rady Administracyjnej departamentu łomżyńskiego (19 XII), następnie prefekt departamentu płockiego (19 । 1808 r.), po wybuchu wojny z Austrią mianowany generalnym intendentem wojsk polskich w Galicji (V 1809 r.), uzyskując przy tym szerokie pełnomocnictwa w zakresie sprawowania zarządu cywilnego. Skutecznie pozyskiwał zasoby zajętych terenów na potrzeby wojenne, co spotkało się z uznaniem ks. Józefa Poniatowskiego, ale także niechęcią szlachty, zarzucającej mu traktowanie Galicji jak kraju podbitego. W Królestwie Polskim był prezesem Komisji Województwa Mazowieckiego (1816 r.), posłem na sejm z powiatu biebrzańskiego (1818 r.), marszałkiem sejmu (1820 r.), wchodził w skład Biura Centralnego Policji dla Warszawy i Królestwa Polskiego (1821 r.) oraz komisji skarbowej (1825 r.). W 1832 r. został zwolniony ze służby państwowej. Był rzecznikiem poprawy losu ludności wiejskiej oraz uprzemysłowienia kraju; uważany jest za twórcę przemysłowej Łodzi; K. Badziak, H. Michalak, Rembieliński Rajmund Hiacynt, h. Lubicz (1774-1841), [w:] Polski Słownik Biograficzny, t. 31/1, z. 128, red. E. Rostworowski, Wrocław - Warszawa Kraków - Gdańsk - Łódź 1979, s. 82-84.

41 Przychodów.

42 W minucie dodano: J[aśnie]O[świeconego].

43 W minucie: sierpnia. 
[s. 71] Fabryka w jakim stanie znaleziona

Co do wielkich pieców

1. Prefektura Samsonowska ma dwa piece zwane wielkie ${ }^{44}$, jeden w Samsonowie, drugi w Szałasie ${ }^{45}$. [46] Pierwszy podług uwagi jest trzyćwierciowy, a drugi węższy i niższy, miary pierwszego niedochodzący. Wielki piec każdy jest głową pięknej nadziei i pewnych pożytków z przedaży żelaza zbieranych, w którym topi się ruda, i surowe żelazo w piasek na gęsi ${ }^{47}$ zlewa się; każda z tych numerami porządkowemi znaczona, każda przeważa się ile cetnarów i funtów surowizny trzyma, i znaki wagę cetnarów i funtów udowadniającemi opatrzona, i ta liczba wagi frysierzom ${ }^{48}$ znajoma, zapewnia ich o wadze niezawodnej, w każdej gęsi zamykającej się, gdy do fryszerni pod młoty wodne biorą. Piec samsonowski rok stał cały nie będąc puszczonym, i to bez opatrzenia w rudę i węgle, a szałaski szedł miesięcy $21 / 2^{49}$. Dopiero rząd militarny ${ }^{50}$ przeznaczywszy Imć Pana Babskiego na dozorcę fabryk, tak samsonowskich jako i suchedniowskich ${ }^{51}$, ten zastawszy pogródki ${ }^{52}$ i galeryję przy wielkim piecu samsonowskim zdezelowane, te zreperować, piec zaprawić, rudę, węgle zwozić i piecem puścić zalecił i puszczonym w dniu dziewiątym miesiąca augusta ${ }^{53}$ został, ale ultimis novembris ${ }^{54}$ pewno stanie, a tak tylko $4^{55}$ [s. 72] miesiące iść przeznacza się, który 40 tygodni, przy opatrzeniu wszystkiego iść był powinien. Ten przez złą rudę, w odbieraniu od górników źle dozorowaną, przez niedostatek węgli, co ich w czasie nie dostawiali, często do wpół pieca i mniej opadał, a na nowo do miary doprowadzając nabijać magister piecowy węglami i rudą musiał ${ }^{56}$, czego sam będąc na tej lustracyi byłem świadkiem, co jest przeciwko regule, a jest i ze szkodą Skarbu, gdy tylko 95 cetnarów surowizny piec wielki wydawał, co zupełnie z złej administracyi pochodziło, a niedozór i niepilność wszystko obwinia.

Popełnione są dwa defekta; raz rudy że niedozorowani górnicy, a ci widząc, iż jaką urobią rudę, taką odbierają, a ta jest najgorsza; wciągnieni górnicy w ten nieporządek swym zarobkom dogadzają a Skarbowi znoszą [sic!] deces ${ }^{57}$. Po drugie, kurzacze ${ }^{58}$ nie-

44 W minucie: wielkie zwane.

45 W minucie: na Szałasie Nowym.

46 Dalszy fragment tekstu w lewej części strony.

47 Według Osińskiego: „Gęś; u pieców wielkich żelazo z rudy wytopione wypuszczają w rów podobny do bruzdy, wypuszczone żelazo gdy ostygnie, robi się z niego sztuka trójgraniasta długa, zowią ją gęś"; J. Osiński, op. cit., s. 75.

48 J. Osiński podaje formę „fryszerz”; ibid., s. 74.

49 W minucie słownie: dwa i pół.

50 Rząd Centralny Tymczasowy Wojskowy Galicji (pierwotnie: „Rząd Centralny Tymczasowy Wojskowy Galicji w Imieniu Napoleona W. Cesarza Francuzów i króla włoskiego") powołany został przez ks. Józefa Poniatowskiego 2 VI 1809 r. Po przyłączeniu Galicji do Księstwa Warszawskiego (na mocy pokoju w Schönbrunn z 14 X 1809 r.) stracił rację bytu, jednak jego formalne rozwiązanie nastąpiło dopiero w grudniu tego roku; D. RychelMantur, Członkowie Rządu Centralnego Tymczasowego Wojskowego Galicji - przyczynek do biografii zbiorowej, „UR Journal of Humanities and Social Sciences” 2020, nr 3 (16), s. 24-25, 33.

51 W minucie: tak suchedniowskich jako i samsonowskich.

52 Według Osińskiego: „Pogrodki, wiązanie z drzewa przy młynach , w którym są koła , żłoby któremi woda na koła płynie"; J. Osiński, op. cit., s. 81.

53 W minucie: sierpnia.

54 z końcem listopada.

55 W minucie słownie: cztery.

56 W minucie: musiał węglami i rudą.

57 Tj. przynoszą stratę.

58 Kurzacze - robotnicy zajmujący się wypalaniem węgla drzewnego w mielerzach; zob. J. Osiński, op. cit., s. 49, $57,79,82$. 
przysposobieni do układania siągów ${ }^{59} \mathrm{w}$ lemierze ${ }^{60}$, które niż przygotują, niż one wypalą, niż dokładnie wykurzą, powołani aby spieszyli z wystawieniem ${ }^{61}$ węgli nie czekając czasu, ale dogadzając potrzebie piątego lub szóstego dnia gaszą i wydają węgle, co powinni byli dotrzymać do dziewiątego lub dziesiątego dnia, aby tym lepiej doszły w milerzach ${ }^{62}$ węgle, na czym już deces gdy na każdym milerzu jest strata czterech lub pięciu koszy węgli, [s. 73] na czym tracą kurzacze, a więcej traci Skarb gdy na siągach niedopalonego drzewa na węgle robi się szkoda.

[63] Ad $1^{\text {mum }}$ Piec wielki, gdy jest w sobie obszerny i ma komin wysoki, zwykł po inszych fabrykach od 160 cetnarów do 250 surowizny wydawać, bierze więcej rudy a mało co więcej ${ }^{64}$ węgli potrzebuje nad potrzebę do węższego i niższego, w czym zaraz kalkulacja węgli korzystniejsza być się widzi. Samsonowski piec jest w sobie za ciasny, ma komin niski, dlatego mało oddaje surowizny, bo jak o tem informowałem się, że choćby ruda najlepsza do niego była przysposobiona, że więcej wydać nie może jak 100, 110, a bardzo rzadko 120 cetnarów. Ku poprawie zaś tego defektu zdawałoby się podnieść komina na łokci 3; a gdy jest futrowany ten piec, podług wiadomości, kamieniem, i tu futrówka od lat 18 będąca, pewnie wypalić się musiała, którą wyłamawszy, cegłą go futrując można zrobić ustępu cali 10, a tak będzie w sobie obszerniejszy. A najdogodniej by było gdyby nie szło o koszt i czas, toby wypadało stary znieść a nowy piec pomurować, gdy już i ten porysowany, toby tyle drugie z siebie wydawał pożytku; rzecz tylko [s. 74] [65] o osadzenie mostu do gichty ${ }^{66}$, a wypada po nim prowadzić węgle, więc trzeba aby był odsadzony, a elewacyja onego nie powinna być przykra, do zawodu w górę prowadzącym gichciarzom węgle taczkami; a co najgorzej, że zastępuje tej sposobności umiarkowanej węglarnia murowana, a więc w takim wypadku trzeba by machinę zrobić, którą by wciągać można z dołu rudę i węgle w górę, wprost na gichtę. A podług powszechnego porządku, kto fabrykę żelazną posiada, którą i ja trzymałem, nim piecem puści winien zaopatrzyć piec 1000 lub więcej wozów rudy, a węgli koszami 500 przynajmniej. Piec zaś puszczając najdogodniej w marcu z wiosny dla pewnej wody i dogodności ludzi koło pieca robiących, lecz takim zapasem opatrzywszy piec jak wyrażam, a łatwiej rudę i węgle częściami dowozić, a dopełniać to co ubędzie.

Co do rudy

[ $\left.{ }^{67}\right]$ 2. Rudę, sam widząc, znalazłem ją najnieczyściejszą, bowiem jeżeli nie więcej, to przynajmniej trzecią część warpy czyli gliny przy sobie mającą ${ }^{68}$, ta z szyb czyli dołów rud-

59 Według Osińskiego: „Siągi, stos drzewa długi i wysoki na trzy łokcie, szeroki na 5 ćwierci łokcia. Siągi układają z drzewa łupanego, aby prędzej wyschło. Od urąbania siąga płaci się po groszy 15, niekiedy więcej , aby ludzi zachęcić. Siągi rąbią i układają od stycznia aż do lipca, bo w lecie łatwo wysychają"; ibid., s. 83.

60 W minucie: siągów w lemierze układać. „Mielerz , Stos z drzewa na kształt stogu porządnie ułożony , z takowego drzewa węgle kurzą; mielerz układają albo z 72, albo z 36 siągów. Jeżeli siągi są suche i miary dobrej, kurzacz ( jako się powiedziało ) z 36 siągów , wydawać powinien 19 koszów węgli; siągi zrachowane oddają kurzaczowi, ten więc doglądać powinien, aby zwożący je na bok drzewa nie zrzucał, lecz na miejsce , na którym mielerz ma zakładać, zwoził"; ibid., s. 79.

61 W minucie: $z$ dostawieniem.

62 W minucie: lemierzach.

63 Dalszy fragment tekstu w prawej części strony.

64 W minucie: a małowięcej.

65 W minucie: idzie.

66 Według Osińskiego: „Gichta albo szychta, dziura czyli gardziel pod kominem na dach pieca wyprowadzonym znajdująca się, tą dziurą w piec węgle i rudę sypią"; J. Osiński, op. cit., s. 75.

67 Dalszy fragment tekstu w lewej części strony.

68 W minucie: warpy w sobie mającej czyli gliny. 
nych przez górników wyprowadzana na ziemię, pod niebo, nie do jat ${ }^{69}$ i nie pod dach przy górach, jak u fabryk innych bywa, zostaje składana; tę gdy pisarz Niemiec rudę odbiera i odmierza [s. 75] od górników wszystką, tę na wielką blisko dołów czyli szybów składać każe kupę ${ }^{70}$ i z tej oddanej z górnikami u tychże szybów rachuje się, zapisuje za oddaną a $w$ domu z niemi kalkuluje i zaspokaja się. A ta ruda pod niebem złożona to śniegiem okrywa się, to deszczem oblewa się, a chociaż wierzch słońca promieniem obsuszać ją zdaje się, jednak w śrzodku ${ }^{71}$ mokra i wilgotna wytrawia substancyję i ile drobna gnić od warpy, czyli gliny przy sobie mającej, koniecznie musi. Zwożąc zaś rudę przed piec wielki na plac pod niebem wystawiona leży, znowu podobnież zlana deszczem, okryta śniegiem, doświadcza tego co u góry doświadczała. Dalej [72] biorą tę rudę na ruszt ${ }^{73}$ mokrą i suchą umieszaną; sucha wypala się, mokra odwilży się tylko, nie sprawi skutków równych gdyby wszystka sucha była. Sam taki skład rudy widziałem, takie onej na ruszcie palenie, a przez to słyszałem sam ${ }^{74} \mathrm{w}$ piecu strzelającą rudę, a to tę, co nie była dopalona, ta rozrzuca węgle, które przedzielają rudę od rudy, a takowej topienie już niedogodne sprawuje, gdy się z sobą przez rozrzucenie węgli połączą. Niemniej jest oddzielna ruda przydrobniejsza, którą u dołu górnicy na nieckach drewnianych [s. 76] płuczą wodą z dołu rudnego [75] nabraną, ale ta woda sama mająca muł tłusty i gliniasty w sobie więcej szkodzi jak pomaga, bo ten muł z wody więcej oblepia rudę niżeli z gliny opłucze.

[76] Ad 2dum W naszych fabrykach, gdzie Polacy mają inspekcyję nad górnikami, nie sprzeciwiają się otworowi szybu czyli dołu, bo Niemcy na sążeń austriacki, któren w sobie zawiera łokci 3 ćwierci 3, nadproporcjonalnie wybijać każą, a u nas na mniejszym przestają, aby próżno ziemi i kamienia nie wyprowadzać, ale rudy brania pilnują; a gdy już górnicy do rudy dobijają się, natychmiast jaty u dołu i daszki z deszczek bitych zakładają, a rudę do tych składają, której ani deszcz, ani śnieg, ani słońce nie szkodzą. A gdy rudę w karniach ${ }^{77}$, to jest w kamieniach, w dołach dobywają, która w dole mokra, mają siekierki małe ze Skarbu wydane, i temi ${ }^{78} z$ warpy czyli gliny ochędożają; a gdy zaś mają drobną do płukania, to tej u dołu nie płuczą, lecz u wielkiego pieca mocą koła wodnego, gdzie przy wale od koła są dwie grace szerokie, pod się zakrzywione założone, które naprzemian ${ }^{79}$ obrotem wału ruszając się płuczą rudę [s. 77] w skrzyniach podobnym mularskim, a do tych skrzyń bywa jedna rynienka napuszczająca wodę do skrzyń, a druga od skrzyń wodę już mulistą odprowadzająca, takową płuczą rudę. A że tu takowej machiny ${ }^{80}$ nie masz,

„Jata, Szopa prosta, dranicami czyli deskami dartemi z trzech stron obita, albo kory drzewa okryta. Takowe szopy przy samym dole stawiają, w nie rudę zsypują, aby jej wilgoć nie szkodziła; z jat przewożą rudę do szopy blisko [wielkiego] pieca będącej"; J. Osiński, op. cit., s. 76.

70 W minucie: kupę każe.

71 W czystopisie: szrzodku.

72 W minucie skreślone: idąc.

73 „Rószt, miejsce z trzech stron wysoko na łokci . obmurowane , na którym rudę przepalają , to jest: układają pomiędzy murami stos z drzewa, i nań rudę sypią, podpaliwszy drzewo, ruda zwolna rozgrzewa się, wilgoci i siarki pozbywa się"; J. Osiński, op. cit., s. 82.

74 W minucie: sam słyszałem.

75 W minucie skreślone: wodą.

76 Dalszy fragment tekstu w prawej części strony.

77 W czystopisie: w karnach. Według Osińskiego: „Karmy , zowią kawały rudy , w których nie masz gliny ani ziemi, czyli rudę kamienną zowią karmy"; J. Osiński, op. cit., s. 77.

78 W minucie: temiż.

79 W czystopisie: naprzemiany.

80 „Płóczka , miejsce w którym rudę mającą wiele ziemi i piasku płuczą, to jest: w koryto obszerne rudę sypią, na 
więc korzystniej by było przy piecu wielkim w skrzynie złożoną rudę, naprawiwszy rynienkę od pogródek piecowych, przez ludzi gracami płukać kazać; kiedy zaś przychodzi po innych fabrykach do odbierania rudy od górników, te $z$ jat ${ }^{81}$ wprost ${ }^{82}$ odmierzają górnicy na fury i one do szopy u wielkiego pieca zbudowanej zabierają. Ta szopa pod dachem będąca ma swoje kojce, gatunki rudy bogatej, śrzedniej ${ }^{83}$ i chudej oddzielające, a tak sucha będąc u dołów, w szopie przy wielkim piecu idzie na ruszt, dopali się zupełnie, bo zawsze sucha, a tu zaś w kluczu samsonowskim odbiórka rudy od górników jest szkodliwa, bo ci sami oddając ją na plac niedaleki swych dołów składają, w nocy z kupy wielkiej do swojej, znowu wyrabiać zaczętej ${ }^{84}$, rudy przenosić i kraść mogą, a częściami po każdym zawozie do pieca rudy te same zabierając drugi raz przedawać potrafią, co koniecznie nastąpić musi. [s. 78] A więc oddalając takowe zdarzenia i wypadki najdogodniej by było, iżby rudę odebraną i odmierzoną wprost do wielkiego pieca wozili, a na ten artykuł sądzę konieczną potrzebę 85 postawienia szop dwóch na skład rudy, u dwóch pieców, tak samsonowskiego jako i szałaskiego; te obydwie najmniejszym kosztem pobudowane być mogą; jest w Samsonowie parkan wielki, trzymający długości sążni austriackich 40, szerokości sążni 24 na przyciesiach, częścią z drzewa tartego, częścią z kostkowego pięknie oprawionego ${ }^{86}$ postawiony, na skład drzewa, mniej potrzebny, a jest nowy, ten rozebrawszy dwie szopy na skład rudy, tak w Samsonowie, jako i w Szałasie, przy wielkich piecach postawić by można, i gonty miejscowe bez kupna użyte być mogą. Co się tyczy potrzebnych jat i daszków ${ }^{87}$ zakładania na rudę, gdy górnikom prze[d]kładałem wyraźną potrzebę tego, przyznali [ją] za sprawiedliwą, mówiąc, iż to bywało za czasów polskich, ale za Niemców upadło, i że do takiego ${ }^{88}$ powrócą się porządku, zapewnili.

Ruda powinna być w zimie znaczną forsą do wielkiego pieca zwożona [s. 79] z dogodności dwojakiej; pierwsza, iż saniami onę wożąc, bierze jej więcej, i to bez szkody, bo jej się nie utrząsa i spomiędzy deszczek nie wypada, a na kołach po kamieniach i korzeniach, wybojach strząsając się ginie wiele; druga dogodność, że ludzie na saniach nic nie tracą, a na wozach i kołach żelazem szybowanych mają stratę gdy im się łamią wozy, koła, a żelazo zdziera. Sprzężaj nie tak się niszczy; ile tu w Samsonowie góry rudne leżą odległe, jako to:

Dalejów ${ }^{89}$ od pieca samsonowskiego ${ }^{90}$ mil 2

Zeberka $^{91}$ ditto $^{92}$ mil $1 \frac{1}{2}$

nią puszczają wodę rynnami, rudę ustawicznie mieszają, przeto ziemia jako leksza z wodą odpływa , ruda zaś w korycie zostaje"; J. Osiński, op. cit., s. 81.

81 W czystopisie: jatów.

82 W minucie: prosto.

83 W czystopisie: szrzedniey.

84 W minucie: zaczętej wyrabiać.

85 W czystopisie: konieczne potrzeby.

86 W minucie: obrobionego.

87 W minucie: jaty i daszku.

88 W minucie: takowego.

89 Kopalnia czynna od XVIII w.; J. Pazdur, Górnictwo w Zagłębiu Staropolskim w epoce feudalnej, „Rocznik Świętokrzyski" t. 1, 1962, s. 165, 174; A.S. Kleczkowski, Rudy żelaza w utworach pstrego piaskowca północnego obrzeżenia Gór Świętokrzyskich, „Prace Muzeum Ziemi” 1970, nr 15, cz. 1, s. 217.

90 W minucie: Samsonów.

91 Kopalnia czynna od XVIII w.; Hieronim Łabęcki podaje kopalnię leżącą w sąsiedztwie wsi o tej nazwie; H. Łabęcki, op. cit., s. 323; J. Samsonowicz, Historja górnictwa żelaznego na zboczu północnem Gór Świętokrzyskich, „Pamiętnik Koła Kielczan” 1928, s. 93; J. Pazdur, Górnictwo, s. 163, 165; A.S. Kleczkowski, op. cit., s. 218.

92 W oryginale: detto 
Świnia Góra ${ }^{93}$ [ditto] mil $1 \frac{1}{1 / 2}$

Dąb $^{94}$ i Grabina ${ }^{95}$ [ditto] mil 1 1/2

Okolec $^{96}$ i Skrzypie [ditto] mil $1 \frac{1 / 2^{97}}{}$

Kitlonka98 [ditto] mil 1

Biała Góra [ditto] mil $1 / 2$

Połaźnia ${ }^{99}$ [ditto] mil $1 / 2$

Miedziana Góra [ditto] mil 1

Perkowski Dół [ditto] mil 1

Za najgorszemi drogami.

Co do górników

[100] $3^{\text {tio. }}$ Za biskupów krakowskich byli górnicy na Miedzianej Górze obsadzeni; ci tylko samem kopaniem rudy byli zajęci, a nie gospodarstwem rolniczem, cząstki tylko najmniejsze ziemi na ogród i łąki mieli wydzielone; dalej z czasem kiedy Miedziana Góra na kopalnię kruszców miedzianych pod osobną dyrekcją wzięła przeznaczenie i odłączona od Samsonowa została, w miejscu więc tamtych górników sami gospodarze po wsiach [s. 80] na gruntach obsadzeni, pańszczyznę odbywający, przyjęli obowiązki górników i takich jest ${ }^{101} 57$ w kluczu samsonowskim a w Miedzianej Górze 6; reszta zaś, to jest 10 górników w górach nie robi i ci co robią, gdy szyby rudne otwierają, one kopią, każdy z tych na dzień po groszy pol[skich] 15 bierze, a że od tych pańszczyzna należy, więc za dzień pieszy groszy piętnaście, a za wołowy złoty pol[ski] 1 utrącają ${ }^{102}$. A gdy rudy dostają od woza tejże rudy biorą zł[otych] pol[skich] 2, a wtenczas strącają ciągłemu za dzień zł[otych] pol[skich] 2 , a pieszemu zł[oty] ${ }^{103} 1$. Wóz rudy trzyma w sobie miary krajowej korzec 1 ćwierci 3. Żaden oficjalista nie bywa u nich tylko hutman - Till ${ }^{104}$, pisarz Niemiec, bywał czasem u gór, a dopiero teraz w czasie lustracyi zaczął bywać częściej.

To jest Stanisława Kukli ${ }^{105}$ hutmana Polaka zeznanie.

[106] Ad $3^{\text {tium }}$ Stan górników z obowiązkiem gospodarstwa połączony nie jest fabrykom ${ }^{107}$ dogodny, bo ich własna miłość dobra polowego i większych pożytków względem siebie uważanych odrywa od roboty, a stąd szkoda Skarbowi dwojaka sprawiać się zdaje. Pierwsza: iż ci, koło gruntu robiąc, opuszczają czas, a spóźniają się w robocie i dosta-

93 Kopalnia czynna w XVIII i XIX w.; J. Pazdur, Górnictwo, s. 173, 165; A.S. Kleczkowski, op. cit., s. 218

94 W drugiej połowie XVIII w. kopalnia ta uważana była za wyeksploatowaną; J. Pazdur, Górnictwo, s. 165.

95 Kopalnia czynna od XVII do XIX w., w drugiej połowie XVIII w. uważana za wyeksploatowaną; ibid., s. 165, 173; A.S. Kleczkowski, op. cit., s. 217.

96 W oryginale: Okulec, w minucie forma właściwa: Okolec. Kopalnia czynna od XVIII w.; ibid., s. 217.

97 W minucie kopalnie: Okolec i Skrzypie wymienione zostały oddzielnie.

98 W minucie forma: Kietlanka. Kopalnia czynna od XVIII w.; A.S. Kleczkowski, op. cit., s. 217.

99 W czystopisie: Położnia, w minucie forma właściwa: Połaźnia. Kopalnia czynna w XVIII w.; ibid., s. 217.

100 Dalszy fragment tekstu w lewej części strony.

$101 \mathrm{~W}$ minucie: jest takich.

102 W minucie: strącają.

103 W minucie: zł[oty] pol[ski].

104 Jan (Franciszek?) Till (Tyl, Theill?); pisarz zatrudniony w dobrach suchedniowskich, w ekonomii samsonowskiej czasowo zastępujący pisarza piecowego Walentego Krzyżanowskiego. Jego obowiązkiem było dozorowanie kopalń i wielkich pieców. Jerzy Szczepański pod 1811 r. wymienia zamieszkałego w Niewachlowie Franciszka Theill'a, byłego pisarza wielkiego pieca w Samsonowie; APR, zesp. 44, sygn. 213, s. 14, 102; J. Szczepański, op. cit., s. 204.

105 Stanisław Kukla w 1809 r. był "hutmanem od gór”, tj. zawiadywał funkcjonowaniem kopalń; APR, zesp. 44, sygn. 213 , s. 98.

106 Dalszy fragment tekstu w prawej części strony.

107 W minucie: fabryce. 
wieniu tyle rudy jaka jej ilość potrzebna, a chcąc wynagrodzićn ${ }^{108}$ spóźnienie spieszą się tylko potrzebie dogodzić, ale nie ugodzić czystości i oprawie [s. 81] tej z gliny; a fabryka, potrzebując pilno rudy, bierze ją jaka jest. Druga: iż już gdy dobiją się rudy, nie odstępując dołu winni onę ciągle dobywać, a gospodarstwo gdy ich zajmuje, odstępują na czas; a woda, gdy nadciągnie, zaleje doły, a los niepewny czy zmogą wylać wszystką wodę z dołu czy nie; a tak, gdy wody nie mogą przebrać, opuszczają dół i traci na tym skarbie Skarb ${ }^{109}$, bo już ta ruda nieodzyskana, która pożytki pewne straciła. Takoż pokazują się skutki najgorszego przez oficjalistów Niemców dozoru górników, a górników z gospodarzy złożonych, leniwo u gór robiących, gdy piec samsonowski rok cały stał, nie będąc puszczanym, a szałaski miesięcy $2 \frac{1}{2} 2$ iść miał, a po roku, za rządu militarnego polskiego, samsonowski miesięcy szedł 4; a tak, czyliż by górnicy, kalkulując każdego górnika rocznie po 100 wozów rudy urabiającego, nie powinni byli przez ten czas 6300 wozów rudy urobić, ile 63 górników robiło [?]; bo chcąc 40 tygodni samsonowskim iść piecem, a tym przestawszy, znowu szałaski puścić, czyżby te dwa piece mogły tyle wytrawić rudy [?]; a te nie idąc tak regularnie jak wypisuję, [s. 82] chcąc się informować o wielości wozów rudy, z opinii, iż jej będzie obficie, przeznaczyłem Pana Romańskiego ${ }^{110}$ ekonoma, aby ten objechawszy góry rudne informował się siła ${ }^{111}$ wozów u gór wszystkich znajdzie rudy; ten podług alegacyi górników, a nie podług pewnego jeszcze dowodu zebrał kalkulacyję i tę podał takową, co zastał gotowej [rudy], jako to:

U góry Dalejowa wozów...150

Świni Góry...275

Dąba i Grabiny...55

Kitlonki112...9

Białej Góry...2

Perkowskiego dołu...22

Suma wozów 513

Teraz tym dowodem rzecz się wyjaśnia, iż opierając się na nadziei korzystnej z górników gospodarzy obiecywanej, fundując się na dobrym dozorze oficyjalistów Niemców, nic skutecznie nie odpowiada, gdy zapasów żadnych nie masz, czyż nie jest szkoda?

Jeszcze dodaję opinię moją, jeżeli za godną uwagi przyjęta będzie, iż ciż górnicy może i niechętnie robią, gdy tylko za dzień od kopania dołów opłacani bywają po groszy poI[skich] 15. Ciężar pracy ich zupełnie nie odpowiada nagrodzie. [s. 83] Czy by nie lepiej było ich wrócić do porządku u nas doświadczonego, gdy nasi górnicy opłacani bywają przy otwieraniu dołu nowego od sążnia gdy ziemię przebijają ${ }^{13}$ złotych pol[skich] 6, gdy zaś w kamie[niu] dubelt złotych $12^{114}$, tym więc ochoczej robić i prędzej do rudy przebijać się będą, bo robiąc za 15 groszy pol[skich] na dzień ociąga[ją] się w robocie, widząc swoją krzywdę. Co zaś od woza rudy złot[ych] pol[skich] 2 biorąc mają dosyć, gdy u nas biorą 3,

108 W rękopisie: wynadgrodzić.

109 W minucie: i na tym skarbie traci Skarb.

110 Józef Romański; ekonom („dyspozytor"), po zniesieniu folwarków w ekonomii samsonowskiej (1806 r.) sprawował nadzór nad wykorzystaniem wołów roboczych oraz użytkowaniem łąk; APR, zesp. 44, sygn. 213, s. 98, 103, 284.

111 Tu w znaczeniu: ile.

112 W minucie: Kietlanki.

113 W minucie: od sążnia ziemię przebijając.

114 W minucie: gdy zaś w kamieniu zł[otych] pol[skich] 12. 
lecz miara [kibli] ${ }^{115}$ jest u nas wyższa, bo trzyma garcy 12, a tutaj 8 , więc jedno drugiemu odpowiada.

Drugą widzę krzywdę ich, że światło do dołów przy dobywaniu rudy muszą sobie kupować, a łoju funt kosztuje teraz złot[ych] pol[skich] 2, a $a^{116}$ oni kupując świec ${ }^{117}$ u Żydów wynosi im w świecach funt za złot[ych] 3, a u nas skarbowe dają świece; lecz w tym potrzebna kalkulacyja, aby nadto świec nie biorąc, onych nie przedawali, o czym wiedząc piszę za niemi, iż w tych zarobkach swoich mają krzywdę, którą sobie nagradzają gdy dobrej nie oddają rudy, lepiej rekwirować $u^{118}$ nich lepszej, a los [s. 84] ich poprawić.

A przeto, według ${ }^{119}$ powszechnego fabryk urządzenia, są oddzielni górnicy, gospodarstwa polowego nie trzymający, samą tylko robotą górniczą zajęci, pilni przy pilności dozorców; już przy dołach rudnych dzień i noc przebywają, szałasy ${ }^{120}$ sobie z chrustów popostawiają i jak mieszkańcy tam uważani, nic ich do domu nie przywiązuje ${ }^{121}$, jak tylko u dołu ich rola, ich zarobek, a tak zawsze pilnie ${ }^{122}$ i pięknie robią. Jednakże prócz mieszkania dla żon i ich dzieci, takowym górnikom udzielnie nadanego, wypada ich zaopatrzyć małą częścią ziemi i łąki, podług porządku wszystkich fabryk zachowującego, iżby mieli jakiś fundusz warzywowy i krowy utrzymania ${ }^{123}$; a w tej spekulacyi, w operacie ekonomicznym pisząc o dwóch folwarkach ${ }^{124}$, trzeci za szczupły jasiowski, z wójtostwa wcielonego pozostały, na lokacyję górników zostawić125 zdawało mi się, ile te folwarczne pola z ogrodem mają tylko w sobie morgów ${ }^{126} 50$, sążni kwadratowych ${ }^{127} 1027$. A tak rozkładając pomiędzy górników 32 toż pole w Jasiowie, na każdego kalkulując po morgów

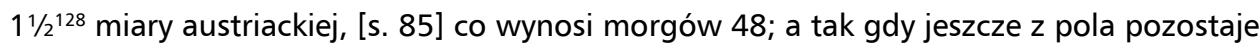
mórg 1 sążni 407, a z ogrodów folwarcznych podobnież mórg 1 sążni 620, które albo pisarzowi górniczemu, albo hutmanowi w folwarku mieszkać mogącemu służyć mogą ${ }^{129}$. Tyleż dodawszy łąki co i pola, z tą tylko różnicą, iżby im otwartej łąki nadać morgę jedną, a pół morgi iżby ${ }^{130}$ sobie wyprawili, gdyż w tej łące jasiowskiej znajdują się obok zarośle. A ta praca podjęta będzie ich samą strażą mocniejszą, że się z miejsca oddalić nie będą chcieli. Bowiem w naszych stronach przy fabrykach górnicy mają pola po dwie morgi z ogrodami i łąki morgę, ale w daleko mniejszej mierze, a płacą z takowego wydziału zło[tych] pol[skich] 24, a tutaj przestać wypada na złot[ych] 16 dla przywiązania ich do miejsca. Z tem rzeczy urządzeniem, iż gdy w tejże wsi Jasiowie są 4 domy dosyć obszerne, zabudowane, izby mające wielkie, a tak tarcicami przepierzywszy każdą izbę i komorę na połowę, dwóch w takowym umieścić się może domu, a [s. 86] dobudowawszy 12 domów

115 Wyraz kibli obecny w minucie, w czystopisie pominięty zapewne omyłkowo.

$116 \mathrm{~W}$ minucie: ale.

117 W minucie: świcę.

118 W minucie: od.

119 W minucie: podług.

120 W oryginale: sałasy.

121 W oryginale: przywięzuie.

$122 \mathrm{~W}$ minucie: pilno.

$123 \mathrm{~W}$ minucie: utrzymania krowy.

124 W minucie: folwarkach dwóch.

125 W minucie: przeznaczyć.

126 W minucie: morgów w sobie.

$127 \mathrm{~W}$ minucie zapis słowny, w czystopisie symbol kwadratu.

128 W minucie: po morgu 1 i $1 \frac{1}{2}$.

129 W minucie: w folwarku murowanym mieszkającemu służyć mogą.

130 W minucie: aby. 
po 2 izdebki i 2 komórki tym jednym kształtem długości i szerokości o jednym murowanym kominie, najpiękniejszą miejscu i wygodzie oddadzą ozdobę. A przy takowych udzielnych górnikach mogliby gospodarze górnicy zimą równo z nimi ${ }^{131}$ robić i podług nich swoje mieć zarobki, jak się i u nas doświadcza, a pańszczyznęę32, którą teraz u gór odrabiają, odrabiać by przy fabrykach mogli.

Co do siągów

[133] $4^{\text {to }}$ Tych zastałem do proporcyi odpowiadającej fabrykom małą bardzo część, o których ilości chcąc być informowanym, dałem rozkaz Romańskiemu ${ }^{134}$ leśniczemu obrachowania onych i te wyrachował po wszystkich miejscach i spisał onych konsygnacyję $\mathrm{w}^{135}$ tej specyfikacyi, jako to:

na Ćmińskiej Górze siągów...219

pod Serbinowem ${ }^{136} \ldots 1696$

na Belnym...491

w Rosochach ${ }^{137} \ldots 905$

na Wiśniówce...997

w Jamie...1165

[138] Te są w najmokrzejszym miejscu, do których przystęp trudny zwożącym siągi na lemierze, i już skargi o to były, że chłopów w te miejsca wypędzają, a bydło dostąpić nie może i przez to woły $\left.{ }^{139}\right]$ pozrywali.

w Łęgach już zgniłych...26

Suma siągów 5499

Z tych, gdy już wypalono jak piszę ...300, więc zostaje...5199.

[140] [s. 87] A jakiż to mały zakład i zapas, który do samych fryszerek nie jest dostarczającym $^{141}$, gdzie powinien być142 obficie opatrzonym rezerwowym nadal, a do wielkiego pieca, na wiosnę chcąc puścić, zupełny deficyt ${ }^{143}$, bo w zimie rąbanych siągów użyć nie można na węgle. Otóż to niemiecki rząd. Ja Polak, z samej czułości o dobro narodowe poruszony, oficjalistów nieczułością, niedozorem, puszczam pióro samą prawdę określające, a jak być należy [i] jak być powinno, opisuję.

Ad $4^{\text {tum }}$ Drzewo na siągi powinni zaczynać siągarze rąbać a mediis decembris per januarium, februarium, martium, aprilem ${ }^{144}$ a koniecznie $w$ tych miesiącach dla pewnego od wiatrów marcowych, kwietniowych wysuszenia, co jest artykułem fabryk i ekonomiki dobrej, do ścinania siągów w tych czasach pożytecznego w uwadze, ale i drugiej obok

$131 \mathrm{~W}$ minucie: $z$ niemi.

132 W oryginale: pańszczyzną.

133 Dalszy fragment tekstu w lewej części strony.

134 Stanisław Romański; leśniczy rewiru samsonowskiego; APR, zesp. 44, sygn. 213, s. 98, 103.

135 W minucie: $z$.

136 W oryginale: Serwinowem.

137 W minucie: Rozsochach, w czystopisie: Rossochach.

138 Pozycje „na Wiśniówce” i „w Jamie” spięte klamrą i objaśnione dalszym fragmentem tekstu, po prawej stronie karty.

$139 \mathrm{~W}$ minucie: i konie.

140 W czystopisie dalszy fragment tekstu omyłkowo w prawej części strony.

141 W minucie: dostarczający; wyraz użyty w znaczeniu: wystarczającym.

142 W oryginale: bydź.

$143 \mathrm{~W}$ oryginale: defficit.

144 Od połowy grudnia przez styczeń, luty, marzec, kwiecień. W minucie fragment tekstu podkreślony: a mediis [decem]bris per januar[ium], februar[ium], martium e[t] aprilum. 
pierwszej, że do takowego rąbania ludzi w czasie zimy prędzej dostać można, a niżeli w czasach ${ }^{145}$ tych, w których pola obrabiać przychodzi ${ }^{146}$. Kalkulacyja ilości urąbania siągów powinna być ${ }^{147}$ przewidziana, a zapas silny, nad potrzeby zbywający powinien być148 uważany, bowiem nikt na zamożności nie traci. Ja z obserwacyi mojej kalkuluję na dwa wielkie piece, które aby nieustannie iść mogły, to jest jeden mając przestawać a drugi zaczynać149, [s. 88] na 5 fryszerek, a szóstą mniejszą, stal z surowego żelaza wyciągającą, kalkuluję potrzebę siągów wyrąbania 20000 tym dyspartymentem, jeżeli siąg każdy wyda węgli kosz jeden; iż, jak przyznawają, że piec samsonowski iść może trzy kwartały ${ }^{150}$, a drugi w Szałasie kwartał jeden, więc na obydwa rok cały kładę, ile jest obowiązkiem gromad kieleckiego i samsonowskiego kluczów, urąbać 10 000, od każdego sążnia zło[ty] pol[ski] 1 opłacając, a 10000 podniósłszy wyżej cenę, gdy najemnicy za takową robić nie będą, dorąbać wypada. A tak do samsonowskiego pieca na każdy tydzień 120 koszów węgli, podług zeznania magistra piecowego gdy wychodzi, a rachuję na tygodni 38, więc wypada węgli koszów 4560, a do szałaskiego pieca na tygodni 14, po 100 koszów węgli na tydzień gdy potrzebują, wydać więc należy [ $\left.{ }^{151}\right]$ koszów 1400; na fryszerek 5, uważając na tygodni 48, dla różnych wypadków reperacyi w roku wydarzanych, a czasem i mrozów tak ostrych, że robić nie mogą, kalkulując do każdego cetnara żelaza kosz jeden węgli, a w każdym tygodniu jak są fryszerki na śrzedniej ${ }^{152}$ wodzie położone, że cetnarów żelaza 20 wykuć by powinny, a tak rachuję [s. 89] na każdą fryszerkę w tydzień po koszów 20 węgli, a więc wypada rocznie koszów 4800, a na fryszerkę szóstą, stalową, mającą mniejszy daleko komin i mniejszy miech, rachuję na 48 tygodni na każdy tydzień po koszy siedem, więc rocznie wynosi koszów 336; a na kowalichy ręczne, do wyrabiania różnych sortymentów i rekwizytów wojskowych, kalkuluję koszów węgli 500. A zebrawszy w komput na potrzebę ogólną wypada dostawić koszów węgli 11 596, a zaręczyć nie można, iżby każdy siąg wydać miał kosz węgli, lecz gdyby wydał, toby zostało siągów 8404, a tak temi superplus zostającemi można do czasu nowych, a już suchych siągów pewno dociągnąć i opatrywać fabryk potrzeby.

Tą jeszcze bacznością i przezornością, iż gdy na mokrych miejscach rąbane siagi zimą bywają, siągi takowe zaraz tą samą zimą przewiezione na suche miejsca być powinny i na takowych wykurzone przez kurzaczów, bowiem z mokrego miejsca porą letnią trudny wywóz siągów do lemierza ułożenia ${ }^{153}$, trudny wywóz węgli, a połowę węgli tracą kurzacze [s. 90] gdyby na mokrym ${ }^{154}$ miejscu wypalać chcieli. Już tu było doświadczone w Samsonowie, że urąbawszy kilkaset siągów jesionowych ${ }^{155}$ i olszowych w miejscu mokrym Łęgi zwanym, tych gdy nie wywieziono ${ }^{156}$ zgniły, a przeto one do gorzelni zabrały, a reszta 26 stoi, już na nic niezdatnych. Takoż gdzie są zwały drzew od wiatrów wywróconych,

145 Zapis zgodny z minutą, w czystopisie: czasiech.

146 W minucie: wypada.

147 W oryginale: bydź.

148 W oryginale: bydź.

149 W minucie: jeden mając zaczynać a drugi przestawać.

150 W minucie: kwartałów trzy.

$151 \mathrm{~W}$ minucie: węgli.

152 Tak w minucie, w czystopisie: szrzedniey.

153 W minucie: ułożenia lemierza.

154 W minucie: mokrem, w czystopisie: mokrym.

155 W oryginale: jasionowych.

156 W minucie: gdy niewywiezione. 
z takowych stawiają się byki ${ }^{157}$ na wykurzenie węgli i takowe węgle bywają używane dla wielkiego pieca, gdy ${ }^{158} z$ różnego gatunku drzewa są złożone. Przed lat ośmiu zwalił wiatr ogrom drzewa w lasach samsonowskich, które dotąd zastępują wzrostowi młodzieży, ale to jakim milionem drzew założył; te już ogniły znacznie, przeto kazałem wybierać co będzie zdatnego na ${ }^{159}$ byki, a co zaś nie leśniczym zaleciłem, izby nie ścinając poddani ${ }^{160}$ drzewa stojącego na opał takowe z lasów wywozili na swoje potrzeby ${ }^{161}$. Szkoda nieodwetowana, przez oficjalistów austriackich sprawiona, co tego na użytek ${ }^{162}$ fabryk nie obrócili ${ }^{163}$, którym by mogli lat 5 i 6 awansować, a ochronić las stojący.

\section{[s. 91] Co do kurzaczów}

[164] $5^{\text {to }}$ Których jest 20, ale w robocie jest ich tylko 10; tych połowę, to jest pięciu, wezwawszy ${ }^{165}$, gdyż druga połowa przy kurzeniu węgli została, przedkładałem ${ }^{166}$ im opóźnienia w dostawie węgli do pieca i o przyczynie badałem, i odpowiedzieli, iż zawczasu niezapowiedzeni o potrzebie i niedostawują im sążni na plac do stawiania lemierzy, skarżąc się, iż przez to sami krzywdę odnoszą, gdy piątego lub szóstego dnia oddawać każą węgle, a te jeszcze nie wystały i nie wypaliły się, a muszą z połowy lemierza wydzielać, drugiej niedokurzywszy połowy, a tak na tym tracą, że niż dojdzie druga połowa, to ogień drzewo trawi, a mniej z tego węgli oddają. Drugie: iż siągi zostały na zbyt mokrych miejscach, po które że i poddani dostąpić nie mogą, i oni nie mają gdzie zakładać milerzów ${ }^{167}$, a niewinni tej szkodzie, że pieca wielkiego opatrywać węglami niedostarczają; rząd winien, ale nie my, odpowiedzieli, jak każą, tak robiemy.

$\left[{ }^{168}\right]$ Ad $5^{\text {tum }}$ Kurzacze powinni mieć, przy dobrym rządzie, swoje pewne zakłady lemierzów, a przystawa siągów na plac ten, gdzie lemierze do kurzenia węgli zakładają, nie powinna być169 opóźniona, zapowiedzenie potrzeby kurzenia węgli powinno ich uprzedzić, a oni skutecznie dopełniać powinni. [s. 92] Lecz oficjaliści sami nie zagrzewając ich, nie zagrażają, nie objeżdżają, lecz w domach, jak widzę, najspokojniej siedzą, a dopiero w potrzebie przynaglają. Przeto wina oficjalistów być170 się pokazuje, a nie wina kurzaczów być $^{171}$ się zdaje. Troskliwy oficjalista względem dobra fabryki nie opuszcza silnego starania, ale wszędzie osobistym byćc ${ }^{172}$ musi, bo fabryka przez najmniejsze opóźnienie wiele

157 Według Osińskiego: „Byk; stos drzewa różnie grubego i długiego, w trzy kondygnacyje na sztorc ustawionego i obrazowanego [tj. formowanego]; byk jest w prawdzie podobny do mielerza, różni się jednak od niego: 1. że kurzacze układają mielerz z siągów w miarę rąbanych, łupanych i suchych, byk zaś składają z kloców nie łupanych, które siągami przekładają; 2. [że] kurzacze składają mielerz z wyznaczonej liczby siągów i ustanowioną miarę węgli z niego oddają, byk zaś według woli układają mniejszy albo większy, przeto nie można im przepisać, aby z niego tyle w szczególności węgli oddawali"; J. Osiński, op. cit., s. 71; Słownik pojęciowy języka staropolskiego, spjs.ijp.pan.pl/haslo/index/8263/25237 [dostęp 21.02.2021].

158 W minucie: gdy, w czystopisie: gdyż.

159 Wyraz zamieszczony w minucie, w czystopisie omyłkowo pominięty.

160 Wyraz dodany w czystopisie.

$161 \mathrm{~W}$ minucie: potrzebę gromady.

162 W minucie: pożytek.

163 W minucie: użyli.

164 Dalszy fragment tekstu w lewej części strony.

$165 \mathrm{~W}$ minucie: $z$ tych połowę wezwawszy.

166 W oryginale: przekładałem.

167 W minucie: lemierzów.

168 Dalszy fragment tekstu w prawej części strony.

169 W oryginale: bydź.

$170 \mathrm{~W}$ oryginale: bydź.

$171 \mathrm{~W}$ oryginale: bydź.

172 W oryginale: bydź. 
traci. Lato dla kurzaczów łatwe i sposobne kurzenie węgli sprawuje, a przed zimą rządny gospodarz fabryki uprzedzić powinien kurzaczów, iżby a mediis octobris ${ }^{173}$ place do ułożenia siągów na lemierze sobie poobierali, one poznaczyli, dawszy rozkaz gromadom do wożenia siągów w różne partyje podług ilości kurzaczów, a kurzacze natychmiast powinni się zabierać do składania siągów zwiezionych na lemierze, te darniami obrazować, opiaskować dla utrzymania onych, do kurzenia zimą, i takowych, przynajmniej jak tutaj 200 lemierzów [174] tylko co do wypalenia gotowych mieć powinni, bo ci, którzy takowego nie mają zapasu, a pod gałązkami świerkowemi i jodłowemi ${ }^{175}$, zamiast razu ziemnego gdy kurzą, nie mają w czasie węgli, a pewną z takowych lemierzów [s. 93] w węglach mają stratę, tutaj zaś i zapasu wielkiego siągów nie mają, a zapasu lemierzy tem bardziej ${ }^{176}$.

Co do fryszerek

[177] $6^{\text {to }}$ Za biskupa krakowskiego, ostatnio posiadającego klucz samsonowski, i za rządu polskiego było fryszerek 9; pierwsza w Kaniowie, druga w Janaszowie, trzecia w Kołomani, czwarta i piąta w Humrze, szósta i siódma na Światełku, ósma i dziewiąta w Suchyniowie $^{178}$. Oprócz tych była na wójtostwie w Jasiowie dymarka i fryszerka za dożywotnika Niewiadomskiego ${ }^{179}$, po którego śmierci rząd austriacki na Skarb odebrał. Lecz gdy powódź wielka zapadła, pozrywała stawy, upusty i pogródki wyniosła, jako to: w Kaniowie, [w] Janaszowie, w Jasiowie ${ }^{180}$, a ostatecznie w Suchyniowie ${ }^{181}$. Z tych koło najpierwszej, w Kaniowie, za rządu austriackiego poczęto nowe pogródki zakładać, a tych nie dokończywszy gdy rząd zmienił się, rząd militarny polski te ukończył, groblą ziemią dosypał, a skoro ta fryszerka ukończona będzie, czego już jest bliska, bo tylko idzie o przybijanie rekwizytów żelaznych, i jak staw nabierze wody, robić będzie mogła. W Jasiowie i Janaszowie zupełnie opuszczone i stawy stoją bez wody. [s. 94] Co zaś w Suchyniowie ${ }^{182}$ przed lat dziesięciu jedna fryszerka za austriackiego rządu ${ }^{183}$ spaliła się, a druga tamże pozostała robiła, lecz gdy woda staw zerwała i ta co czystowała spustoszona stoi i już na nic zdatna. A tak więc tylko pozostało 5 fryszerek do roboty zdatnych, gdyż szósta obrócona na robotę stali, w której stalmajster ${ }^{184} \mathrm{z}$ surowego żelaza stal wyciąga.

[185] Ad 6 ${ }^{\text {tum }}$ Fryszerka w Kaniowie stoi na małej wodzie i za każdą powodzią pod niebezpieczeństwem stawu zerwania zostaje, gdy staw jest górny, a ku pogródkom ostro zniżony, a tak cały ciężar wody wspiera się na podródkach i upuście.

173 Od połowy października. W minucie: 8bris

174 W minucie: już na całą zimę.

175 W minucie: to świerkowemi, to jodłowemi.

176 W minucie: więcej.

177 Dalszy fragment tekstu w lewej części strony.

178 W minucie: Suchedniowie.

179 Jan Nepomucen Niewiadomski; pułkownik kawalerii narodowej, wraz z żoną Katarzyną z Zientarskich posesor wójtostwa w Jasiowie na mocy przywileju nadanego 10 IX 1783 r. przez administratora biskupstwa krakowskiego prymasa Antoniego Kazimierza Ostrowskiego (1713-1784); APK, zesp. 1, sygn. 10200, s. 155; Z. Guldon, J. Kaczor, op. cit., s. 44; H. Dymnicka-Wołoszyńska, Ostrowski Antoni Kazimierz h. Grzymała (1713-1784), [w:] Polski Słownik Biograficzny, t. 24/3, z. 102, red. E. Rostworowski, Wrocław - Warszawa - Kraków - Gdańsk 1979 , s. 540-546.

$180 \mathrm{~W}$ minucie omyłkowo powtórzono tu zapis: w Janaszowie.

181 W minucie: Suchedniowie.

182 W minucie: Suchedniowie.

$183 \mathrm{~W}$ minucie wyraz omyłkowo pominięty.

184 W oryginale osobno: stal majster.

185 Dalszy fragment tekstu w prawej części strony. 
Dwie fryszerki na Humrze są na śrzedniej ${ }^{186}$ wodzie i są w dobrym stanie, robią obydwie gdy mają wody [pod] dostatkiem, a gdy zaś śrzednio ${ }^{187}$, to albo obydwie na przystawkę wody robią, albo też jedna musi wakować, a druga robić, a gdy mała woda, to wtenczas choć $^{188}$ jedna robić będzie, to nie ukuje [więcej] jak 12 cetnarów, a za woda wielką każda z tych ukuć może po cetnarów 16 do ${ }^{189} 18$ na tydzień.

Dalej po sobie na Światełku są dwie fryszerki, stoją już na lepszej wodzie i każda z tych ukuje po cetnarów 18 i 20 na tydzień, aby tylko węgle dostawiane były, na których frysierzom często zbywa, jak sami powiadali.

[s. 95] Co zaś na Suchyniowie ${ }^{190}$, z gruntu nowe trzeba stawiać fryszerki, nowe pogródki i upusty dawać, groble zawozić, a te, podług wiadomości powszechnej, najlepsze być miały fryszerki i najlepszą miały ze wszystkich stojących wodę.

A że ze dwóch pieców wielkich, ciągle idących, znaczne ulanie surowizny spodziewane, a wykuć na teraz egzystujące fryszerki żadnym sposobem nie zmogłyby. Przeto w Suchyniowie ${ }^{191}$ obydwie fryszerki jak były do dawnego przyprowadzić wypada stanu, a oprócz tych wypadałoby na walnej wodzie i rzece Bobrza zwanej, we wsi takoż ${ }^{192}$ Bobrzy nazywającej się, postawić dwie fryszerki, gdzie każda by mogła na każdy tydzień wykonywać po 30 cetnarów, a młyn tam egzystujący znieść, tym udowadniając, iż musi być ${ }^{193}$ na wielkiej wodzie, gdy jest o trzech kamieniach, i płaci z tego młyna młynarz rocznie złotych polskich 1576, a z młynków innych, wyższych, jak jest najpierwsza fryszerka w Kaniowie, opłacają rocznie po zł[otych] ${ }^{194} 45$ młynarze, a więc to samo utwierdza, iż na małej wodzie gdy jest fryszerka postawiona, to i nadzieje ${ }^{195} \mathrm{z}$ wykucia podobnież słabe znaczą się, a więc [s. 96] niżej pozostałe puste dwa stawy, po sobie następujące, na których były dwie fryszerki jasiowska i janaszowska, podobnież małą by posiadały wodę, a zatem zamknąć by te dwa stawy koniecznie wypadało i na rezerwowe one przeznaczyć, a w potrzebie wodę upuszczać na zasilenie, tak stawu samsonowskiego, przy wielkim piecu będącego, jako i fryszerek niżej będących. To temi, jak wypisuję - jak będą postawione fryszerki - robiące ${ }^{196}$, będą za dostateczne i wykuć wszystkę surowiznę mogą, a tak znacznie podwyższy się intrata.

$\left[{ }^{197}\right]$ Stalmajster [ $\left.{ }^{198}\right]$ bierze z najprzedniejszej materyi, lany surowiec, bo z samego wierzchu zbierany, nie zabierając fusów ${ }^{199}$ w blachy na cetnary, gdzie z dwóch cetnarów takowej surowizny oddać powinien stali surowej cetnar 1 funtów $8 \frac{1}{6}{ }^{200}$, a żużle od tego

186 W czystopisie: szrzedniey.

187 W czystopisie: szrzednio.

$188 \mathrm{~W}$ minucie: chociaż.

189 W minucie: $i$.

190 W minucie: Suchedniowie.

191 W minucie: Suchedniowie.

192 W minucie: także.

193 W oryginale: bydź.

194 W minucie: zł[otych] pol[skich].

195 W czystopisie: nadziie.

196 W minucie: robiąc.

197 Dalsza część tekstu na całej szerokości strony.

198 Alternatywna lekcja: steelmajster; w minucie: stal magister.

$199 \mathrm{~W}$ minucie: fusu.

$200 \mathrm{~W}$ minucie: $8 \frac{2}{6}$. 
odchodzące, mające [201] jeszcze nieco substancyi żelaznej, powinny być202 osobno składane i te do wielkiego pieca zabierane dla przetopienia takowych. Ta zaś stal surowa nie jest jeszcze doskonała, bo pod rafinacyję brana bywa.

Na koniec dołącza się inwentarz budowli i rekwizytów ruchomych do fabryk żelaznych należących. Tudzież konsygnacyja do fabryk potrzebnej pańszczyzny ${ }^{203}$.

Dan w Samsonowie dnia piętnastego listopada $1809^{\circ}$ roku.

Michał Odrowąż Strasz lustrator ${ }^{204}\left[{ }^{205}\right]$.

\section{Bibliografia}

\section{Źródła}

Archiwum Państwowe w Kielcach [APK], zesp. 1 Rząd Gubernialny Radomski, sygn. 10200 Lustracja klucza samsonowskiego, 1789 r.

Archiwum Państwowe w Radomiu [APR], zesp. 44 Zarząd Rolnictwa i Dóbr Państwowych Guberni Radomskiej, Kieleckiej, Lubelskiej, Siedleckiej, sygn. 213 Lustracja ekonomii samsonowskiej, 1809 r.

\section{Literatura przedmiotu}

Anusik Z., Strasz (Odrowąż Strasz) Michał z Białaczowa h. Odrowąż (ok. 1740-1824), [w:] Polski Słownik Biograficzny, t. 44/2, z. 181, red. A. Romanowski, Warszawa - Kraków 2006, s. 210-213.

Badziak K., Michalak H., Rembieliński Rajmund Hiacynt, h. Lubicz (1774-1841), [w:] Polski Słownik Biograficzny, t. 31/1, z. 128, red. E. Rostworowski, Wrocław - Warszawa Kraków - Gdańsk - Łódź 1979, s. 82-84.

Słownik języka polskiego, t. 8, red. W. Doroszewski, Warszawa 1966.

Dymnicka-Wołoszyńska H., Ostrowski Antoni Kazimierz h. Grzymała (1713-1784), [w:] Polski Słownik Biograficzny, t. 24/3, z. 102, red. E. Rostworowski, Wrocław - Warszawa - Kraków - Gdańsk 1979, s. 540-546.

Encyklopedia historii gospodarczej Polski do 1945 roku $(A-N)$, red. A. Maczak, Warszawa 1981.

Encyklopedia historii gospodarczej Polski do 1945 roku (O-Ż), red. A. Maczak, Warszawa 1981.

Gąsiorowska-Grabowska N., Z dziejów przemysłu w Królestwie Polskim 1815-1918, Warszawa 1965.

Guldon Z., Kaczor J., Górnictwo i hutnictwo w Staropolskim Okręgu Przemysłowym w drugiej połowie XVIII wieku, Kielce 1994.

Herbst S., Z dziejów wojskowych powstania kościuszkowskiego 1794 roku, Warszawa 1983. 
Ihnatowicz I., Gospodarka polska od rozbiorów do upadku Księstwa warszawskiego. Kształtowanie się układu kapitalistycznego, [w:] B. Zientara, A. Mączak, I. Ihnatowicz,

Z. Landau, Dzieje gospodarcze Polski do roku 1939, Warszawa 1988, s. 297-346.

Instrukcja wydawnicza dla średniowiecznych źródeł historycznych, Kraków 1925.

Kalendarzik Polityczny, Chronologiczny i Historyczny na Rok Panski 1811 z Magistraturami Krajowemi, Warszawa 1811.

Kleczkowski A.S., Rudy żelaza w utworach pstrego piaskowca północnego obrzeżenia Gór Świętokrzyskich, „Prace Muzeum Ziemi” 1970, nr 15, cz. 1, s. 193-218.

Krygier E., Z historii budownictwa zakładów wielkopiecowych w Zagłębiu Staropolskim.

Samsonów 1778-1822, „Kwartalnik Historii Kultury Materialnej” 1965, nr 1, s. 11-36.

Krzymkowski M., Pilarczyk P.M., Protokoły Rady Ministrów Księstwa Warszawskiego, t. 1 (1808-1809), Poznań 2015.

Instrukcja wydawnicza dla źródeł historycznych od XVI do połowy XIX wieku, red. K. Lepszy, Wrocław 1953.

Łabęcki H., Górnictwo w Polsce. Opis kopalnictwa i hutnictwa polskiego pod względem technicznym, historyczno-statystycznym i prawnym, t. 1, Warszawa 1841.

Medyński M., Od III rozbioru do końca pierwszej wojny światowej, [w:] P. Kardyś, K. Zemeła, M. Medyński, T. Wojewoda, S. Piątkowski, G. Miernik, M. Zawisza, Suchedniów monografia historyczna miasta i gminy, Suchedniów 2019, s. 85-211.

Mencel T., Galicja Zachodnia 1795-1809. Studium z dziejów ziem polskich zaboru austriackiego po III rozbiorze, Lublin 1976.

Niemcewicz J.U., Podróże historyczne po ziemiach polskich między rokiem 1811 a 1828 odbyte, Paryż - Petersburg 1858.

Osiński J., Opisanie polskich żelaza fabryk..., Warszawa 1782.

Pazdur J., Materiały do dziejów hutnictwa żelaza w Polsce w XVIII wieku, „Studia z Dziejów Górnictwa i Hutnictwa" t. 1, 1957, s. 319-359.

Pazdur J., Górnictwo w Zagłębiu Staropolskim w epoce feudalnej, „Rocznik Świętokrzyski" t. 1, 1962, s. 151-183.

Rychel-Mantur D., Członkowie Rządu Centralnego Tymczasowego Wojskowego Galicji przyczynek do biografii zbiorowej, „UR Journal of Humanities and Social Sciences” 2020, nr 3 (16), s. 23-38, DOI 10.15584/johass.2020.3.2.

Samsonowicz J., Historja górnictwa żelaznego na zboczu północnem Gór Świętokrzyskich, „Pamiętnik Koła Kielczan” 1928, s. 85-99.

Siembab M., Wójcik A.J., Zarys dziejów huty żelaza w Ząbkowicach (1763-1794), Warszawa 2020.

Szczepański J., Modernizacja górnictwa i hutnictwa w Królestwie Polskim w I połowie XIX w. Rola specjalistów niemieckich i brytyjskich, Kielce 1997.

Wójcik Z.J., Świętokrzyskie w relacjach podróżniczych Juliana Ursyna Niemcewicza, [w:] Mijające krajobrazy Polski. Świętokrzyskie, red. A. Rembalski, Kielce 2014, s. 163-174.

\section{Strony internetowe}

Minakowski M.J., Hełczyńscy: szlachta, mieszczanie czy frankiści?, minakowski.pl/helczynscy-szlachta-mieszczanie-czy-frankisci/ [dostęp 28.02.2021].

Słownik pojęciowy języka staropolskiego, spjs.ijp.pan.pl/haslo/index/8263/25237 [dostęp 21.02.2021]. 
geneteka.genealodzy.pl/index.php?op $=$ gt\&lang $=$ pol\&bdm $=B \& w=07 \mathrm{mz} \&$ rid $=$ B \&search_lastname $=$ Strasz\&search_name $=$ Michał\&search_lastname2 = \&search_name2$=\&$ from_date $=1744 \&$ to_date $=1744 \&$ exac $=1$ [dostęp 28.02.2021].

\section{Podziękowania}

Autor składa podziękowanie Panu dr. Maciejowi Jasińskiemu za konsultację łacińskich fragmentów tekstu.

dr inż. Bartosz Kozak, absolwent dziennych studiów magisterskich i doktoranckich na Wydziale Leśnym Szkoły Głównej Gospodarstwa Wiejskiego w Warszawie oraz niestacjonarnych studiów doktoranckich w Instytucie Historii Nauki im. L. i A. Birkenmajerów PAN w Warszawie, doktor nauk leśnych w zakresie leśnictwa (2011 r.) oraz doktor nauk humanistycznych w zakresie historii - historii techniki (2019 r.). Od 2020 r. zatrudniony w Pracowni Historii Techniki Instytutu Historii Nauki im. L. i A. Birkenmajerów PAN w Warszawie. Autor kilkudziesięciu publikacji dotyczących historii regionu świętokrzyskiego. Członek Polskiego Towarzystwa Turystyczno-Krajoznawczego oraz Kieleckiego Towarzystwa Naukowego. e-mail: bartosz.kozak@ihnpan.pl

Data zgłoszenia artykułu: 4 marca 2021

Data przyjęcia do druku: 16 maja 2021 